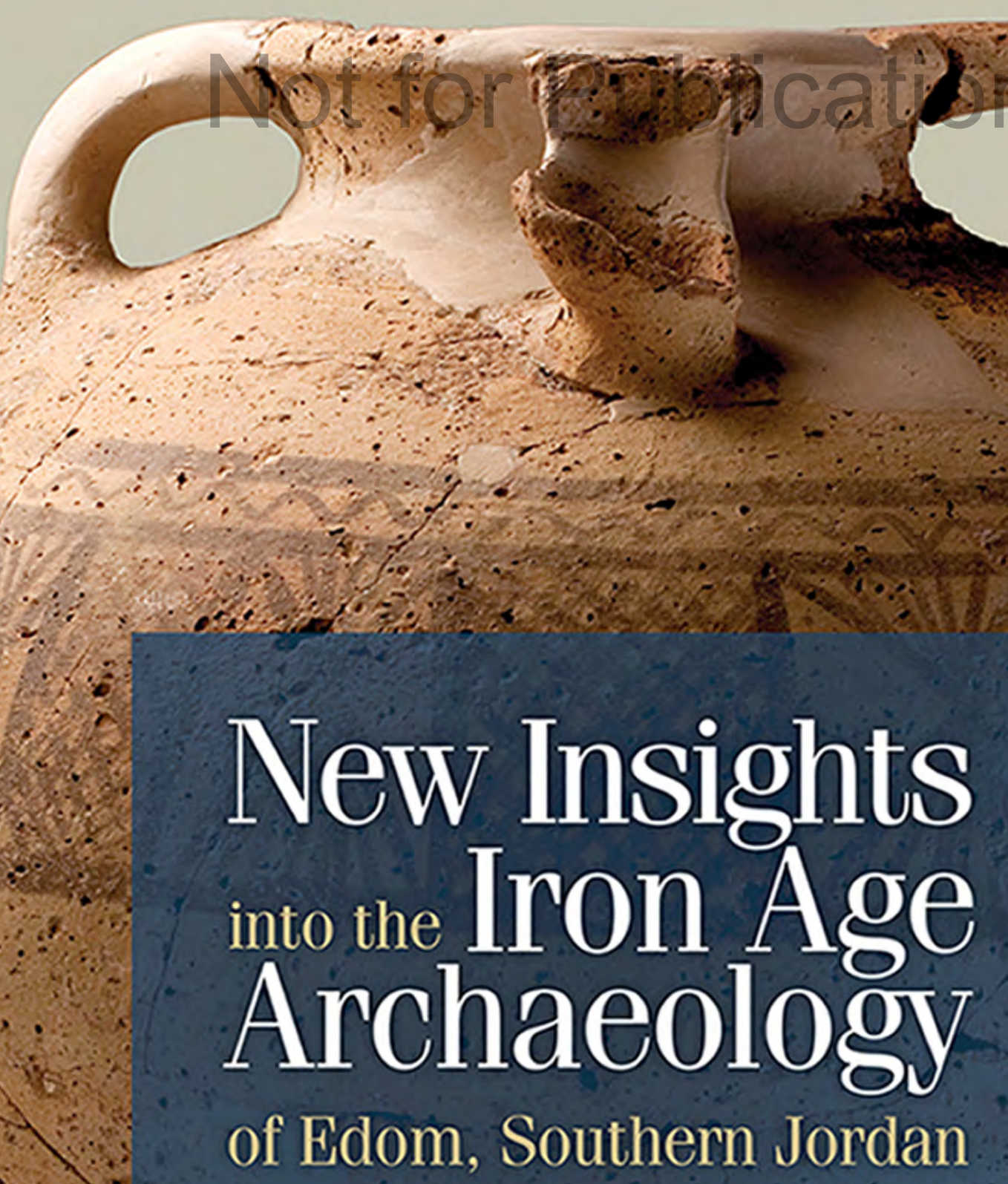

Volume 2

Thomas E. Lewy, Mohammad Najjar, and Erez Ben-Yosef 


\section{Not for Publication}

\section{TABle of Contents}

Author Affiliations $\quad$ ix

List of Figures $\quad$ x

List of Tables xviii

The DVD Supplementary Digital Photography of Excavation, Survey
and Artifacts, and Chapter Materials

\section{ChAPTER 6}

Local Iron Age Trade Routes in Northern Edom

From the Faynan Copper Ore District to the Highlands

Erez Ben-Yosef, Mohammad Najiar, and Thomas E. Levy

\section{CHAPTER 7}

Patterns of Iron Age Mining and Settlement in Jordan's Faynan District

The Wadi al-Jariya Survey in Context

Kyle A. Knabb, Ian W. N. Jones, Mohammad Najjar, and Thomas E. Levy

\section{Chapter 8}

Feeding the Iron Age Metalworkers at Khirbat en-Nahas: Zooarchaeological Data

Adolfo Muniz and Thomas E. Levy

\section{Chapter 9}

Wadi Fidan 40 and Mortuary Archaeology in the Edom Lowlands

Marc A. Beherec, Mohammad Najjar, and Thomas E. Levy

\section{Chapter 10}

A Picture of the Early and Late Iron Age II in the Lowlands

Preliminary Soundings at Rujm Hamrat Ifdan

Neil G. Smith, Mohammad Najjar, and Thomas E. Levy 


\section{Not for Publication}

viii New Insights into the Iron Age Archaeology of Edom, Southern Jordan

\section{CHAPTER 11}

The Iron Age Egyptian Amulet Assemblage

Stefan Münger and Thomas E. Levy

\section{Chapter 12}

New Iron Age Excavations at Copper Production Sites, Mines, and Fortresses in Faynan

Erez Ben-Yosef, Mohammad Najiar, and Thomas E. Levy

\section{Chapter 13}

The Material Culture of Iron Age Copper Production in Faynan

Erez Ben-Yosef and Thomas E. Levy

\section{Chapter 14}

The Iron Age Edomite Script and Language

Methodological Strictures and Preliminary Statements

Christopher A. Rollston

\section{ChAPTeR 15}

Conclusion

Thomas E. Levy, Mohammad Najjar, and Erez Ben-Yosef

Index 


\section{Stefan Münger and Thomas E. Levy}

The assemblage of glyptic objects, which include scarabs and other amulet types, sheds light on the vivid interaction between the people living in Iron Age Edom and Egypt during the twenty-first and the beginning of the twenty-second Egyptian dynasty (ca. 1070-850 BCE).

Given the peripheral location of the investigated area, far off from regular transport axes, and the industrial nature of the investigated copper sites, the number of Egyptian stamp seals and amulets is astonishing, especially during a period when contacts with Egypt were normally observed on the Mediterranean coast and along transregional trade routes.

However, while some of the Egyptian goods unearthed in tombs may be the result of the nomadizing Shasu tribes' social interaction with neighboring groups, the presence of these items within Edomite copper production centers could reflect commercial and/or cultural interconnections of the local population with the Egyptian realm at the close of the second and at the beginning of the first millennium BCE.

This chapter summarizes the entire corpus $(n=16)$ of Egyptian amulets found in the surveys and excavations of the Edom Lowlands Regional Archaeology Project in Jordan's Faynan district. The majority $(n=10)$ come from the stratified excavations at the Khirbat en-Nahas copper production center located on the Wadi Ghuwayba. Three items are from an Iron Age tomb from Wadi Fidan 4, two from the large Iron Age cemetery at Wadi Fidan 40, and one found on the surface of Khirbat Hamra Ifdan, also on the Wadi Fidan. This assemblage contributes to understanding the nature of Egyptian interaction with this important southern Levantine copper production zone.

Opposite: Collection of Egyptian amulets from the UC San Diego-Department of Antiquities of Jordan Edom Lowlands Regional Archaeology Project. (Images not to scale) 


\section{Introduction}

The small but significant assemblage of Egyptian amulets found during the course of excavations and surveys carried out by the University of California, San Diego (UCSD)-Department of Antiquities of Jordan (DOAJ) Edom Lowlands Regional Archaeology Project (ELRAP) shed important light on the nature of Egyptian-Levantine interaction during second and first millennium BCE. The amulets were found primarily in stratigraphic excavations at the copper production site of Khirbat en-Nahas and the contemporary Wadi Fidan 40 cemetery that the ELRAP team links to the Shasu nomads referenced in ancient Egyptian texts such as the Harris Papyrus and the Papyri Anastasi (Giveon 1971; Levy, Adams, and Muniz 2004; Ward 1972). While no definitive conclusions can be made about what role the Third Intermediate Period Egyptians had in the Faynan copper ore district, the data demonstrate important social interaction that can be factored into different models and interpretations discussed throughout this volume.

In terms of the study presented here, a number of qualifications need to be outlined. The glyptic expert (Münger) could not inspect the objects in person, and all observations were made by means of photographs. Equally, measurements were taken according to the photographs rather than from the actual objects.

A capital letter followed by a number (e.g., H6) refers to the "List of Hieroglyphic Signs" in Gardiner (1957:438-548).

Parallels marked with " are of unknown stratigraphic attribution, or altogether have none; ${ }^{(*)}$ indicates an uncertain stratigraphic attribution or find context; and ○ designates a surface find. A superscript "?" signals a tentative interpretation or a hesitant attribution.

Analogous objects in the "Parallels" section have been included only if corresponding examples from authorized excavations are available (comparanda kept in museums or private collections are cited only if essential to the discussion). No comprehensive presentation of parallels was attempted.

This study follows the nomenclature and chronology of the southern Levant according to Stern (1993) (except for the absolute dating of the Iron Age I, cf. Münger 2003, 2005; for the dates of the Egyptian dynasties, cf. von Beckerath 1999).

In what follows, the context of each amulet is presented, followed by a detailed description of the object, a discussion of its meaning, parallels in the scholarly literature, and finally its date. When taken together, in the conclusion, it is possible to make some preliminary observations concerning the nature of Egyptian interaction with Faynan, especially during the tenth century BCE.

\section{Cat. No. 1: Scarab-Amun-Re (Figure 11.1)}

Registration Details and Context: Wadi Fidan 4 (WFD 4), Area H, Season 2003, Tomb 1, Locus 758, Basket 1948, EDM 40046/50208. Wadi Fidan 4 (WFD 4) is primarily an Early Bronze I site located west of the Wadi Fidan gorge that cuts through the Jabal Hamrat Fidan (Adams and Genz 1995) and situated southeast, across from the Wadi Fidan 40 cemetery on the south bank of the wadi. While the UCSD-DOAJ ELRAP team was excavating WFD 4, a series of tumuli were identified along the northern edge of the site, overlooking the wadi. Two of these tumuli were sampled as they were in danger of looting. The tomb was made up of a $25-\mathrm{m}^{2}$ rock cairn that covered a cist grave identical to those found in the Wadi Fidan 40 cemetery across the wadi (see Chapter 9 , this volume; Levy, Adams, and Muniz 2004). Unlike the WFD 40 cemetery, the isolated Iron Age tombs at WFD 4 and the newly excavated Iron Age tomb on the summit of Wadi Fidan 61, these outlier tombs contain unusually large numbers of buried individuals. Thus, Tomb 1 at Wadi Fidan 4, with eight buried individuals (see Chapter 9, this volume), played a different role in Iron Age mortuary rituals in Faynan. While no radiocarbon dates have been obtained, at the end of this chapter, an assessment is made of its dating based on the assemblage of Egyptian amulets found there and discussed in this chapter.

Object: Scarab; typologically belonging to Group B of the Early Iron Age Mass-Produced Series (EIAMS; cf. Münger 2005:394 with examples; see also Cat. No. 10, below). ${ }^{1}$

Condition: Small chip on plinth is broken off; there is slight damage near the drilling on the scarab's rear. Engraving: Bold linear and hollowed-out engraving. Material: Enstatite. ${ }^{2}$ Color: Yellowish brown. Dimensions: $11.7 \times 9.5 \times 6.0 \mathrm{~mm}$.

Base: The base is vertically arranged and shows several degenerated hieroglyphs. The vertical line on the right-hand side may represent a $j$ (M17 or alternatively šwt, H6; cf. Keel 1995:\$456.461). The sign $m n$ (Y5; Keel $1995: \$ 457)$ is clearly visible in the center. The horizontal line above might be an $n(\mathrm{~N} 35$; Keel 1995: $\$ 458) .{ }^{3}$ The two short horizontal strokes below the $m n$ should be 


\section{Not for Publication}

interpreted as two $r^{\varsigma}$ (N5; Keel 1995:\$461). The first sign on top corresponds to the hieroglyph $h^{6}(j)$ (N28; Keel 1995:\$453).

Discussion: The hieroglyphs in the lower two-thirds of the plinth combine to form the name of the $\operatorname{god} \operatorname{Jmn} R^{\circ}$ «Amun-Re». The top most sign, however, should not be interpreted as $h^{\prime}(j)^{4}$ but as a space filler (as first suggested by Brandl 1993a:135-136, No. 10, for somewhat earlier but graphically similar motifs), which occasionally occurs in connection with the name of Amun-Re (for parallels from the southern Levant and Egypt, see Brandl 1993a and Keel 1997:684-685, No. 62; see also Cape Gelidonya: Brandl 2003:Pl. 1, SC 2). Brandl (1993a:136) dates this peculiar space filler to the nineteenth Egyptian dynasty.

Parallels: Although the written name of Amun-Re is quite frequently found in the corpus of the EIAMS, ${ }^{5}$ only one item shows a similar arrangement. It comes from Grid 33 at Ashkelon and was found in an Iron Age III context (cf. Keel 1997:716-717, No. $75=$ Münger 2011:154) (catalogue entry Aškelon 3).

Dating: As object EDM 51101 typologically clearly belongs to the EIAMS, it should be dated accordingly, from around 960 to $900 / 880$ BCE or somewhat later (corresponding to the final years of the twenty-first and the beginning of the twentysecond Egyptian dynasty; cf. Münger 2003, 2005). In view of the degenerated, yet almost illegible rendering of the originally nineteenth Egyptian dynasty motif, a late production date during this time span may be assumed (see also the poorly engraved items from later contexts at Tell el-Far'ah South; Münger 2005:Figure 23.1).
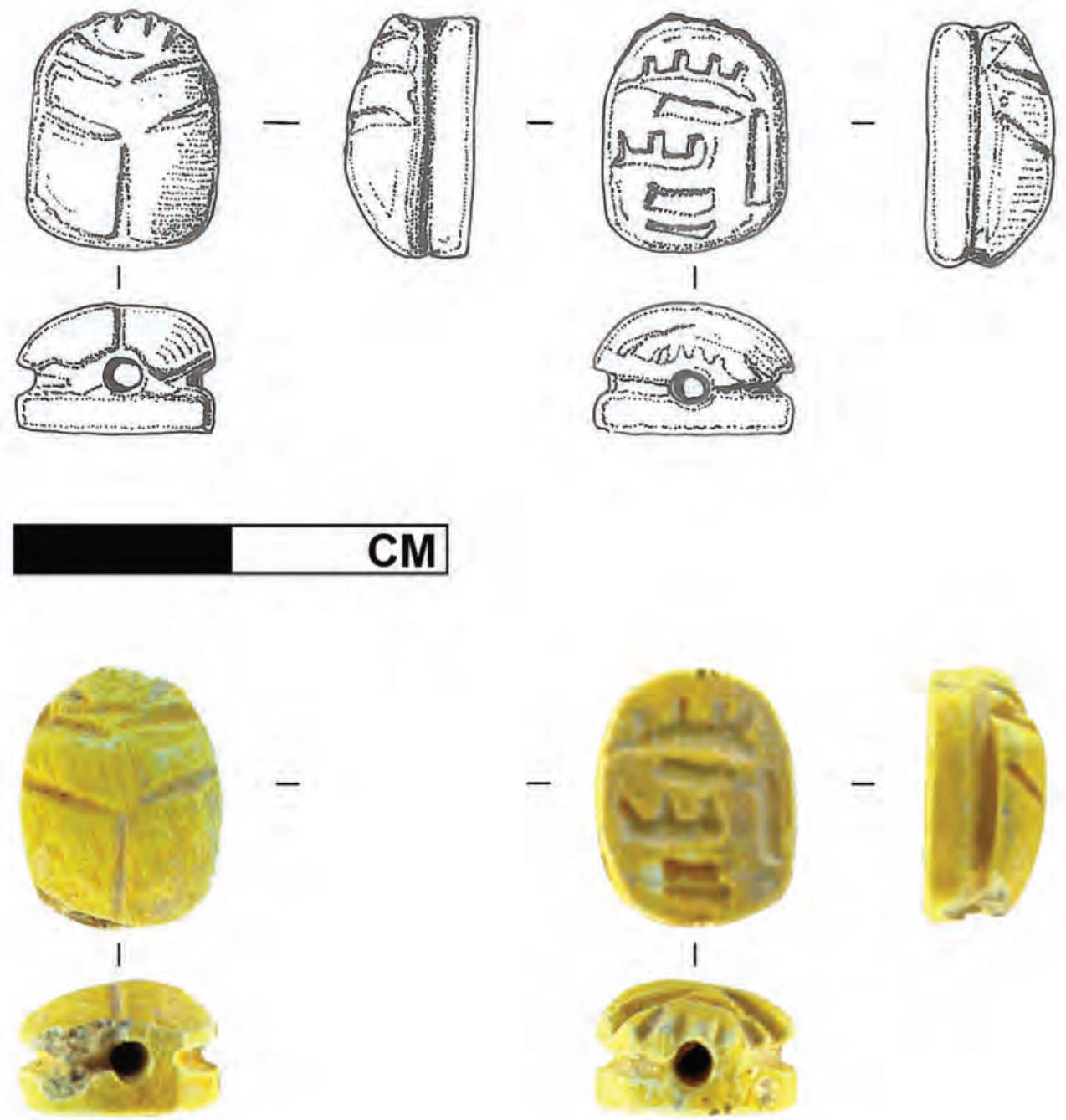

Figure 11.1 Scarab of Amun-Re found in Tomb 1, Wadi Fidan 4, EDM 51101, L758, B1948. 
Cat. No. 2: Figurine AmuletStanding Female (Figure 11.2)

Registration Details and Context: Wadi Fidan 4 (WFD 4), Season 2003, Area H, Tomb 1, Locus 701, B1613, EDM 50700. This item was found in the Tomb 1 multiple burial in a cist grave, beneath the rock cairn at Wadi Fidan 4 in association with a semi-flexed adult who had copper (possibly bronze) anklets-one on each leg, along with a number of beads and cowrie shells. Unfortunately, the sex of this individual has not yet been determined (see Chapter 9, this volume).

Object: Figurine amulet of a standing female figure with a high (double) crown. The arms are hanging down along the body, and one leg seems to be placed slightly ahead of the other, which gives the impression that the figure is advancing. The right leg is damaged; otherwise, the item is complete but very worn. Hardly any details of the head are visible except for eyes, nose, and mouth. Traces on the chest could be the remains of an original necklace; below, the belly button is visible. The back is plain; there is a suspension hole at the height of the figure's ears. Measurements: $2.1(\mathrm{H}) \times 0.8$ $(\max . \mathrm{W}) \times 0.6(\max . \mathrm{D})$.
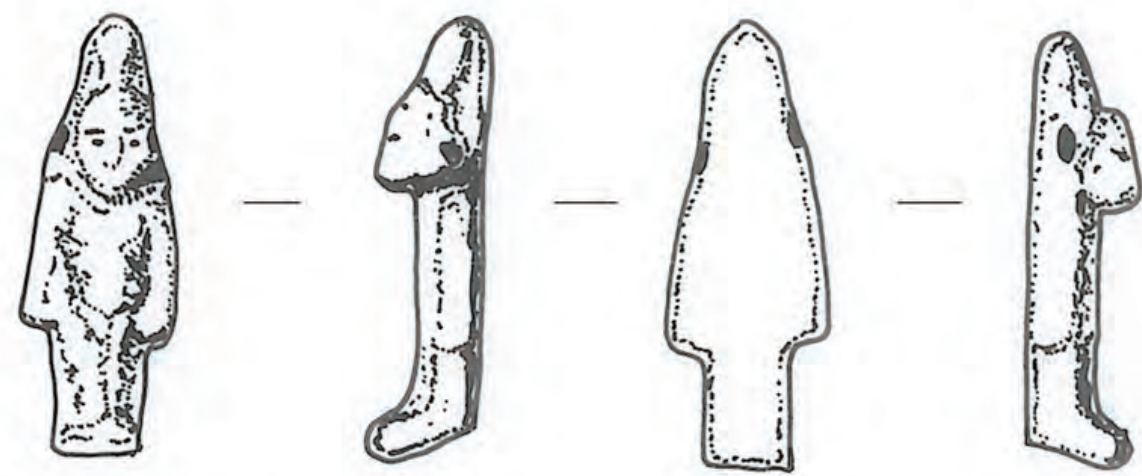

\section{CM}
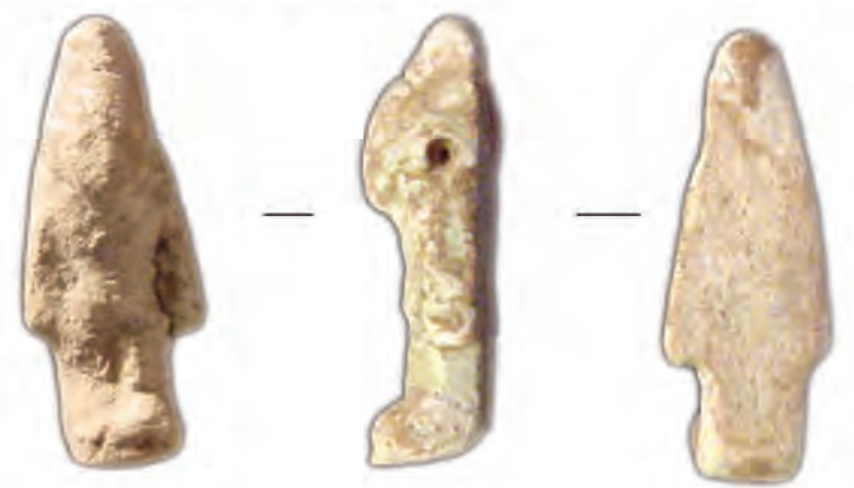

Material and Production Technique: Whitish composition, no remaining traces of glaze; mold-made (see also Cat. No. 9, below).

Parallels: This type of figurine corresponds to Herrmann's type 1.10.B ("Gestalt mit Doppelkrone, schreitend"; cf. Herrmann 1994:209-210). A comparable amulet comes from an Iron Age IB or early IIA context at Tell Abu Hawam, Stratum IV: Hamilton (1934:34 with Pl. 35,213; for the dating of the context, cf. Balensi et al. 1993:10-11).

Date: On the basis of the parallel from Tell Abu Hawam, an Iron Age IB/Early Iron Age IIA date, roughly corresponding to the twenty-first Egyptian dynasty (1070/69-946/45 BCE), is suggested.

\section{Cat. No. 3: Rectangular Piece- \\ "Amun Is My Lord" (Figure 11.3)}

Registration Details and Context: Wadi Fidan 4 (WFD 4), Season 2003, Area H, Tomb 1, Locus 720, Basket 1775, EDM 50809. Tomb 1 at Wadi Fidan 4 was exceptionally rich in imported Egyptian amulets. Preliminary analyses of the fragmentary human remains suggest that this was an adult age 20 to $50+$ years of undetermined sex. Even though this 
tomb was robbed in antiquity, it still contained a rich assemblage of Egyptian imports, suggesting that this adult was a prestigious individual.

Object: Bifacial rectangular piece, type II (Keel 1995:\$\$220-224), perforated lengthwise. Condition: Fully preserved. Engraving: Bold linear and hollowedout engraving. Material: Enstatite. Color: Beige. Dimensions: $11.1 \times 9.2 \times 5.4 \mathrm{~mm}$.

Side A: Vertically arranged scene-framed by a simple line-showing a falcon-headed deity with one arm raised and the other arm hanging down along the body. Above the deity's head is a sun disk. To its right is a rearing uraeus (cobra) with a long tail (jrt ${ }^{\mathrm{c}}$; I12/13; cf. Keel 1995: \$522).

Side B: Horizontally organized hieroglyphs (from right to left): $j$ (M17; Keel 1995:\$456), $m n$ (Y5; Keel 1995:\$457) with a complementary $n$ (N35; Keel 1995: $\$ 458$ ) below (for a similarly executed $n,{ }^{6} \mathrm{cf}$. , e.g., an item from ${ }^{(*)}$ Ashkelon: Keel 1997:726-727, No. 103), and three short vertical lines that should be viewed as determinative strokes. ${ }^{7}$ On the far left is a vertically arranged $n b$ (V30; Keel 1995:\$458).

Discussion: Side B reads Jmn $n b<j>$ «Amun is my Lord», as it is, for example, found on an item from Tell el-‘Ajjul, Tomb 1035 (Keel 1997:176-177, No. 216; see also Tell el-Far'ah South, Tomb 960C: Keel 2010b:336337, No. 725 [without determinative strokes]). Note that there is a plethora of parallels to this formula, which usually reads «Amun-Re is my Lord» (cf., e.g., Beth Shean, Level VI: Keel 2010a:116-117, No. 42 with many parallels).

The falcon-headed deity spreading its wing(s) protectively over a uraeus is a common motif in the glyptic art of the New Kingdom. A strikingly similar parallel for Side A comes from an Iron Age IIA context at Kadesh Barnea, Stratum 4B, which equally features on its reverse side the name of Amun, though cryptographically written (Münger 2007:No. 1 with further explanations and comparanda ${ }^{8}$ [add, e.g., the oval piece with sheaf-shaped handle found at Ekron, Stratum VIA: Keel 2010a:548-549, No. 69, with additional parallels]).

Parallels: A very fine-although unfortunately stratigraphically unclear-comparandum comes from Area A at (")Tell el-Fukhar (Acco); cf. Keel (1997:628629, No. 274; for a bifacial rectangular piece with the name of Amun-Re that was found in Transjordan at Tell es-Sa'idiyeh, Tomb 90, see Eggler and Keel 2006:376377, No. 19). While the item from Tell el-Fukhar (Acco)
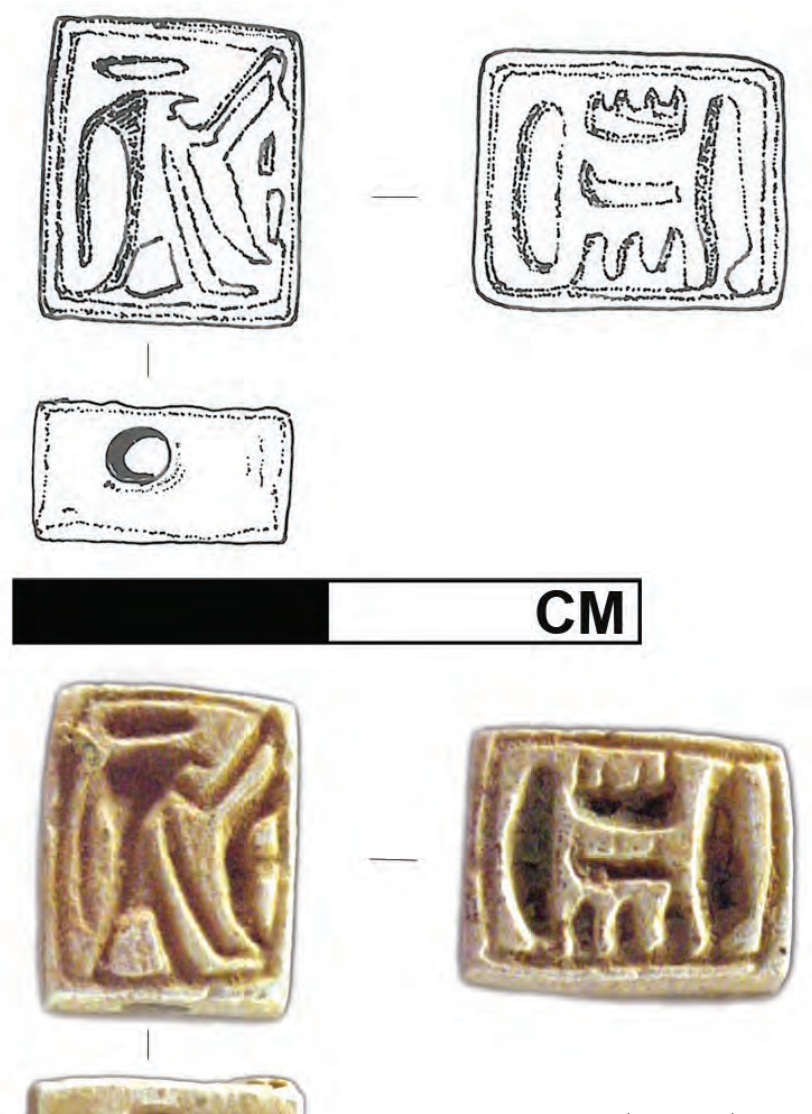

Figure 11.3 Rectangular amulet"Amun is my Lord," Tomb 1, Wadi Fidan 4, EDM 50809, L720, B1775.

is much larger in size than the item from Wadi Fidan, it similarly has a falcon-headed deity with a uraeus on one and the name of Amun(-Re) on the other side. Keel (1997:628) dated this item to the late nineteenth and the twentieth dynasties (ca. 1250-1075 BCE).

Dating: Bifacial rectangular pieces of type II clearly had their heyday during the Ramesside period (ca. 1292-1070/1069 BCE). After the Late Bronze Age IIB, they are much less frequent but still might have been produced (Keel 1995:\$222 and 224). In view of the mentioned parallel from Tell el-Fukhar (Acco), a Late Bronze Age IIB/Early Iron Age I date is suggested.

\section{Cat. No. 4: Scarab-Crowned Uraeus}

\section{(Figure 11.4)}

Registration Details and Context: Wadi Fidan (WFD 40), Season 1997, Area A, Grave 92, Locus 531, Basket 2152. Grave 92 was one of the first systematically excavated tombs in the Wadi Fidan 40 cemetery (Levy et al. 1999). Like most of the graves, 
this one was disturbed in antiquity, as evidenced by the removal of one of the capstones covering the rectangular cist. However, this grave was also relatively rich in burial offerings, including a well-preserved wooden bowl with spout that was filled with pomegranates. The interred was an adult female oriented north and facing west. This woman was also buried with an iron bracelet on her left arm, copper anklets on each leg, two copper rings (one on a toe from each foot), a necklace made of beads accompanied by the scarab described below, and other objects. The first radiocarbon dates from the Wadi Fidan 40 cemetery were taken from desiccated pomegranates found with this individual (see Chapter 9, this volume). The calibrated (1 sigma) date from this short-life sample is 1015 to $845 \mathrm{BCE}$. As the scarab described below dates to the MB IIB period, we assume that this was an heirloom that reflects Egypt-Edom interaction during the Hyksos period. As will be noted in the conclusion, this find is important in that it may illustrate kind of interaction alluded to in Egyptian papyri and other inscriptions from the fifteenth to tenth centuries BCE (Giveon 1969-1970, 1971; Levy, Adams, and Muniz 2004).

Object: Scarab; type D5 (head), 0 (back), e9 (side) according to Tufnell (1984). Condition: Chipped along the border of the plinth. Engraving: Linear engraving with hatching. Material: Enstatite. Color: Dark reddish brown. Dimensions: $18.5 \times 12.4 \times 11.2 \mathrm{~mm}$ (measurements after Eggler and Keel 2006:484).

Base: The center of the vertically arranged plinth is dominated by an upraising uraeus (Keel 1995:\$529) with a red crown (Keel 1995:\$452) flanked on each side by a $z 3$ "protection» (V16; Keel 1995: $\$ 465)$ atop of a $n f r$ «good, perfect» (F35; Keel 1995:\$459).

Discussion: The motif on the plinth belongs to Tufnell's design class 3A3 (Tufnell 1984:Pl. 8a,b) and is typical for an early Middle Bronze Age II scarab group dubbed by Daphna Ben-Tor's "Early Palestinian Series" (Ben-Tor 2007:126); for crowned uraei in central position, which are flanked by various signs, compare with, for example, (")Rishon Leziyyon, transitional MBIIA to MBIIB tomb (Ben-Tor 2007:Pl. 51,23; for the context, cf. Ben-Tor 1997:162-163; Levy 1993); Tell el-'Ajjul, Tomb 1337 (Keel 1997:434-435, No. 974); and Lachish, Tombs 153 and 6027 (Tufnell 1958:Pl. 32,76.118). ${ }^{9}$ It is probable that the seal was locally produced.

Parallels: Close parallels of the scarab's type and the motif on its plinth come from Tel el- Dab'a, Tomb $5 \mathrm{~A} /$ II-1/14 = Stratum E/1, which is dated to 1620 to 1590
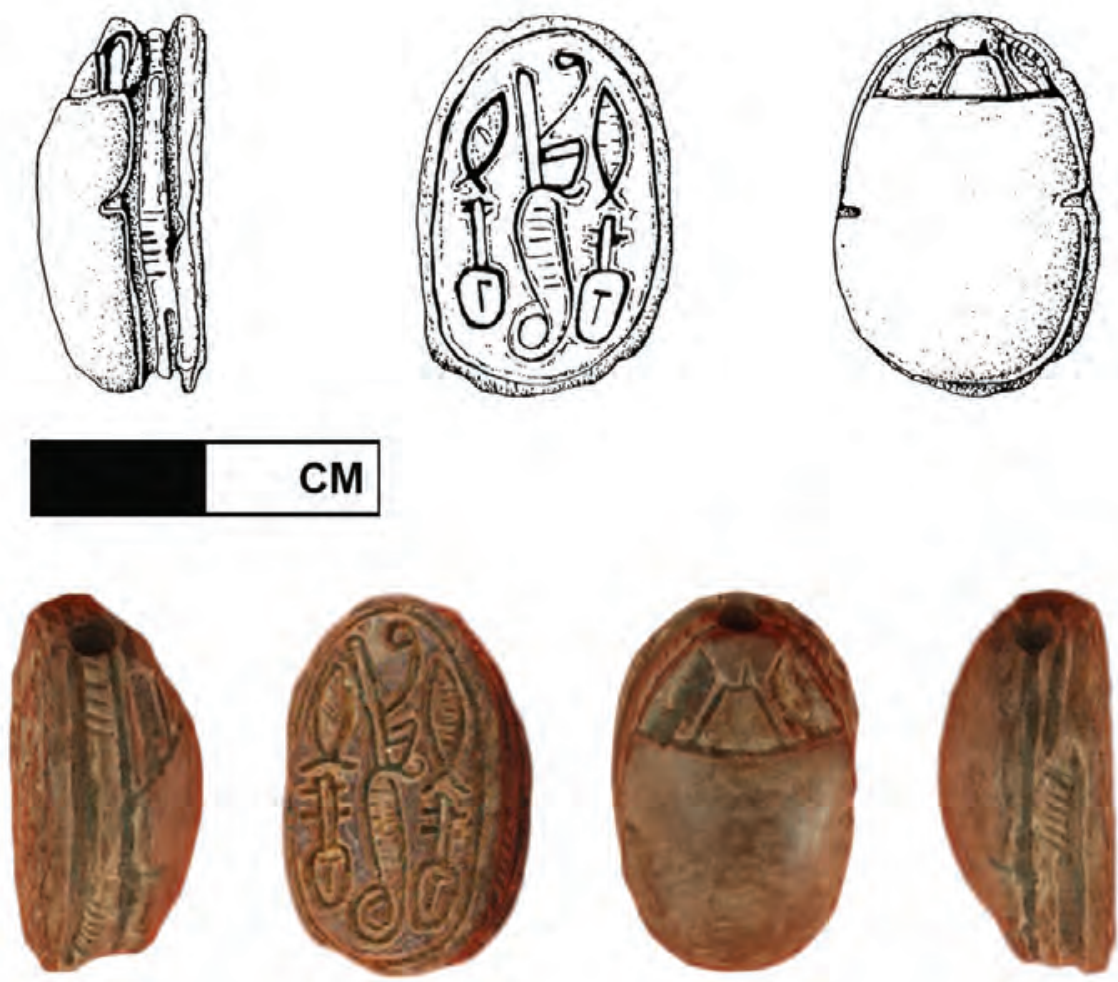

Figure 11.4 Scarab-crowned uraeus from the Middle Bronze IIB, Wadi Fidan 40 cemetery, Grave 92, EDM 86873, L3050, B2983. 
BCE, that is, to the first part of the Hyksos's rule in Lower Egypt (Mlinar 2004:129), and from Megiddo, Tomb 24 (Guy 1938:Pl. 105,14). Note, however, that on the base of each of these examples, the uraeus is flanked by two vertically positioned $z 3$ to each side (instead of a $z 3$ and atop a $n f r$ ).

Dating: Middle Bronze Age IIB (ca. 1700-1630 BCE; cf. Ben-Tor 2007:119).

Bibliography: Levy et al. (1999:299-300 with Figure 6 ) and Eggler and Keel (2006: Wadi al-Feidan Friedhof 40, No. 1).

\section{Cat. No. 5: Rectangular Seal with Sheaf Shaped Handle (Figure 11.5)}

Registration Details and Context: Wadi Fidan 40 (WFD 40), Season 2004, Area A, Grave 91, Locus 3050, Basket 2983, EDM 86873. This tomb may represent a reuse of the original cist structure associated with the burial monument. The removal of the southern slab of the cist to accommodate this extended burial points to this interpretation. As suggested by Beherec et al. in Chapter 9 (this volume), the rectangular stamp seal and the other Egyptian artifacts found in the Wadi Fidan 40 cemetery and other tombs in the region were relatively rare finds. While they are quite common at Levantine sites around the southern Levant, their rarity in Faynan may indicate individuals of high status. Thus, the interred individual, or some closely related family member, may have used the stamp seal found in Grave 91. The reuse of the tomb suggests that a number of generations living in Faynan made use of the cemetery.

Object: Almost rectangular "piece with sheaf shaped handle” (Keel 1995:\$210.212-213 [type II]). Keel catalogued well over 20 items from Israel/ Palestine (in Keel et al. 1990:355-360, updated in Keel 1995:\$212; further see Ashkelon, Iron Age II context: Keel 1997:728-729, No. 108) to which, for example, the following from Cis- and Transjordan should be added: Beth Shean, Stratum II-I (Keel 2010a:166-167, No. 155); Ekron, Stratum VIA (Keel 2010a:548-549, No. 69); Sahab, Tomb C (Eggler and Keel 2006:258259, No. 1); and Tell es-Sa'idiyeh, Tomb 354 (Eggler and Keel 2006:380-381, No. 29).

Contrary to other seals of this type, which normally tend to be more oval, the plinth of the present item from Wadi Fidan 40, Grave 91 is almost rectangular; similar in shape are Tell Abu Hawam, Stratum IIIB (Keel 1997:6-7, No. 7); Tell el-Far'ah South, Tombs
133 and 52410 (Keel 2010b:120-121, No. 217 and 128-129, No. 233); or Gezer, Tomb 96 (= Stratum VIII; cf. Dever 1974:4; Macalister 1912: III: Pl. 90,30). ${ }^{11}$

Condition: The seal is somewhat worn; its plinth is slightly damaged (the upper part of the fourth vertical stroke is apparently broken along the outer edge and some smaller parts are chipped off, especially in the center of the plinth). Engraving: Bold linear engraving. Material: According to the excavators, the seal is made of limestone. This is very unusual since "oval/rectangular pieces with sheaf shaped handles" are almost exclusively made of composition (Keel 1995:\$394-395) with a greenish or bluish glaze (but cf., e.g., Basel: Museum für Völkerkunde: Hornung and Staehelin 1976:Nos. 17-18, where the material "Steatite" is indicated-although with a question mark). Color: Yellowish brown. Dimensions: $14.5 \times$ $10.5 \times 8.0 \mathrm{~mm}$; with these measurements, the seal is among the smallest of its type (a seal with similar dimensions is, e.g., the seal from Tomb 133 at Tell elFar'ah South mentioned above).

Base: The base should most probably be viewed horizontally. It shows four vertical strokes flankingtwo on each side-an endwise-vertical rectangle, which is horizontally divided by two additional lines into three segments.

Discussion: The decoration on the seal's base is uncommon, and no exact parallel can be found. However, on the basis of comparative material, it might be suggested that this geometric pattern imitates or alludes to the divine name Jmn "Amun», similar to seals of the same type bearing debased renderings of the name of this Egyptian deity, although to a lesser extent.

Parallels: The closest parallel to the engraving on the seal's base is an unstratified item from "Gezer: Macalister (1912: II: 322, No. 217 and III: Pl. 207,30). Other "pieces with sheaf shaped handles" bearing the defectively (vertically arranged) written name of Amun are, for example, items from Tell Abu Hawam, Stratum IIIB (cited above); Tell el-Far'ah South, Tomb 643 (Keel 2010b:156-157, No. 295) and "Stratum" Y (Keel 2010b:378-379, No. 830); and Timna South, Site 200 (Hathor sanctuary), Locus 107 (Schulman in Rothenberg 1988: Eg.Cat. 189, p. 138 with Fig. 46,9 and Pl. 123,6).

Dating: Insofar as none of the seals in question bears a datable inscription (i.e., a pharaonic name that is likely to be contemporaneous with the seals' production), ${ }^{12}$ it is appropriate to give a relative date. Among the earliest 
find spots is the one from Sahab (see above) where a "rectangular/oval piece with sheaf shaped handle" was found in a tomb chamber that mainly contained LBI-II material (Dajani 1970:30). However, it cannot be ruled out that this seal was deposited at a later time, since Tomb C at Sahab was in use until the Iron Age IIB. ${ }^{13}$ Another case is the seal found in the Hathor sanctuary at Timna South (see above) that is dated to the nineteenth to twentieth dynasties (1292-1075 BCE). ${ }^{14}$ Nevertheless, all other stratified items from Cis- and Transjordan were found in contexts dating to the Iron Age IB or later. In view of the debased engraving on its base and the unusual material used (which might point to a local production), a date for this seal from Grave 91 at the end of the twentieth to the twenty-first Egyptian dynasty (ca. 1100-950 BCE) is suggested (see also Keel 1995:\$213 with earlier literature).

Bibliography: Levy, Najjar, Muniz, et al. (2005:470471) and Eggler and Keel (2006: Wadi al-Feidan Friedhof 40, No. 2).
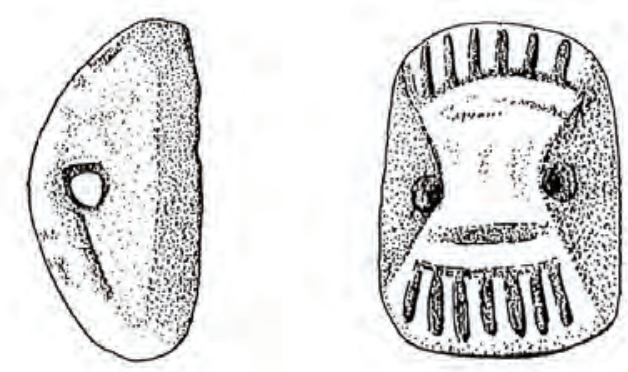

\section{Cat. No. 6: Scarab-Sheshonq I (Figure 11.6)}

Registration Details and Context: Khirbat Hamra Ifdan خربة حمرة إفدان (WFD 120), Season 2006, Surface, EDM 12189. This scarab is the most significant Iron Age Egyptian artifact found to date in southern Jordan. The scarab was discovered by UCSD graduate student Ben Volta during a field trip to the Early Bronze Age copper production site of Khirbat en-Nahas led by T. E. Levy. Volta was walking around the site while the undergraduate students were being given a tour. The site is situated on an isolated, naturally defended mesa or inselberg situated in the middle of the Wadi Fidan. Approximately $100 \mathrm{~m}$ south of the northernmost point of the plateau site, Volta found the Sheshonq I scarab on the surface. There is an absence of architectural remains that date to the Iron Age at Khirbat Hamra Ifdan. However, a well-preserved Iron Age slag mound is situated in the southern aspect of the site that was probed by the UCSD team in 2007. A radiocarbon date from the 2000 excavations in Area L at the site
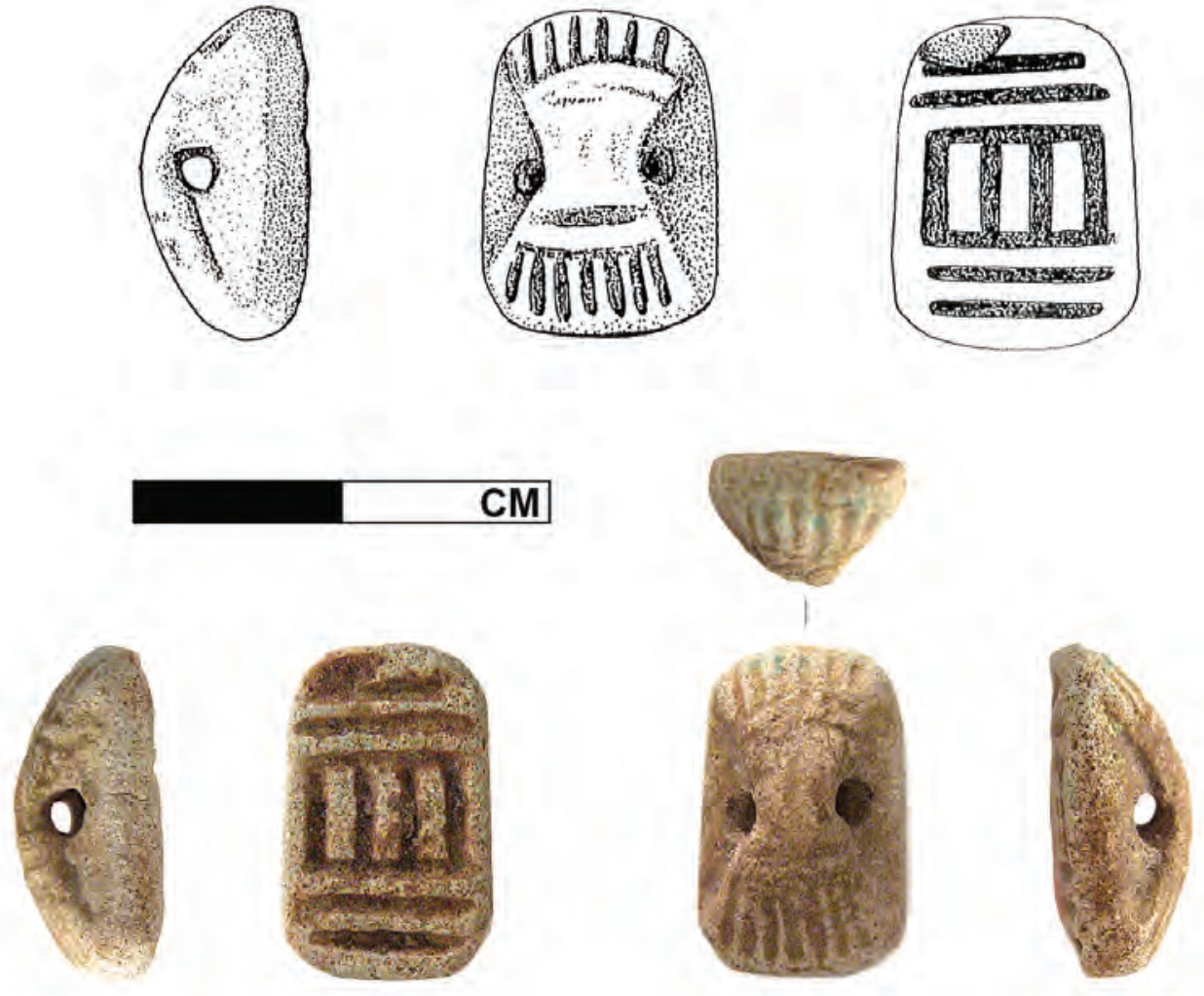

Figure 11.5 Rectangular seal with sheaf-shaped handle, Wadi Fidan 40, Grave 91, EDM 86873, L3050, B2983. 
confirms that Iron Age copper production activities took place at the site $(2910+41 \mathrm{BP}: 1192-1021 \mathrm{BCE}$ with a 68.2 percent probability and 1261-995 with a 95.1 percent probability; see Levy et al. 2012:207208), as does the technological artifacts found at the site (see Chapter 13, this volume). In an earlier publication, Levy et al. (2008) suggested that the
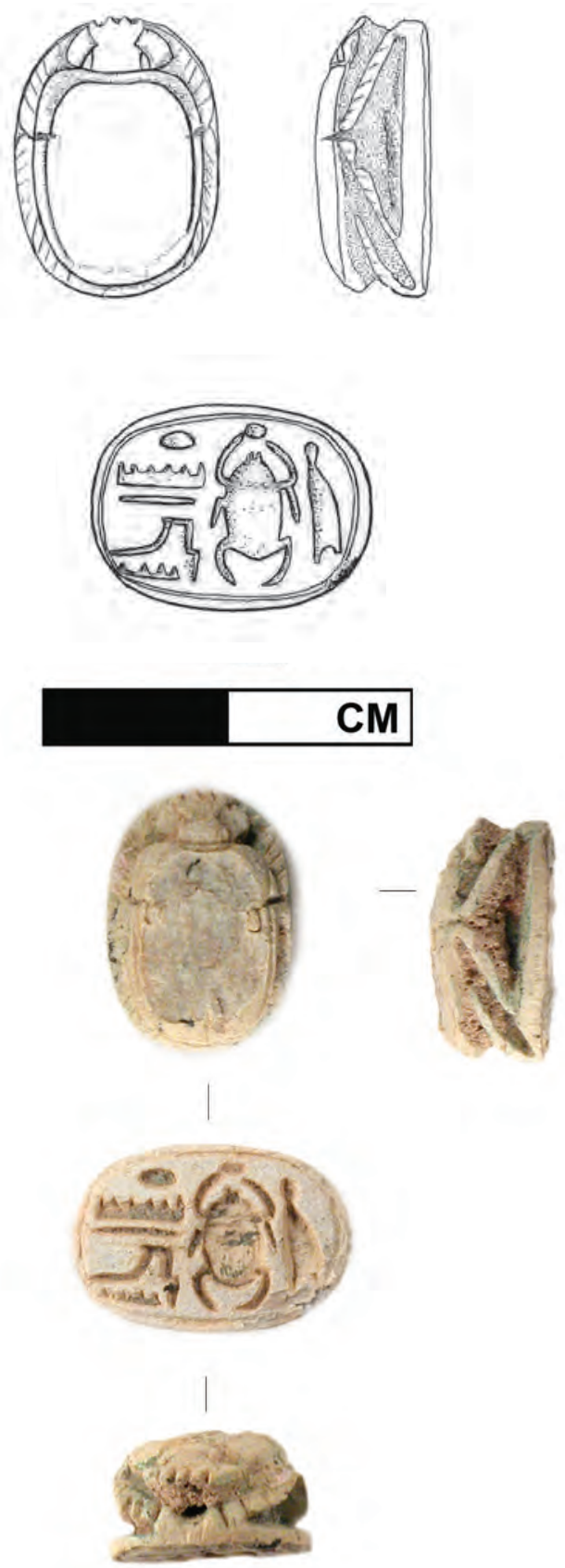

Figure 11.6 Scarab-Sheshonq I, Khirbat Hamra Ifdan, Wadi Fidan, Jordan. disruption of copper production at Khirbat en-Nahas observed in the slag mound in Area M (see Chapter 2, this volume) may have been attributed to the military activities of Sheshonq I's army during their campaign in the southern Levant. This is discussed in greater detail in the conclusion below.

Object: Scarab. Condition: The back is chipped and the border of the plinth slightly damaged along the right side. Engraving: hollowed-out and linear engraving.

Material: Enstatite. Color: Light brown with traces of green glaze in the recesses. Dimensions: $12.7 \times 9.2 \times$ " $5.5 \mathrm{~mm}$.

Base: The plinth is horizontally arranged and bordered by a thin line. The enclosed hieroglyphs read (from right to left): $h d \underline{d} t$ (S1; Keel 1995: $\$ 453$ ) and hpr (L1; Keel 1995:\$454) with a small $r^{\star}$ (N5; Keel 1995:\$461) between the scarab beetle's forelegs, followed to the left by $\operatorname{stp}$ (U21) atop an $n$ (N35; Keel 1995: $\$ 458)$; above these two signs are again a $r^{\circ}$, a $m n$ (Y5; Keel 1995:\$457) and a second $n$.

Discussion: The hieroglyphic sequence $h d-h p r-R^{*}$ stp.n-(J)mn-R" "bright is the manifestation of Re, chosen of Amun/Re» corresponds to the throne name of the founder of the twenty-second Egyptian dynasty, Sheshonq I (946/45-925/924 BCE; cf. von Beckerath 1997:191; see also Shortland 2005).${ }^{15}$ If this attribution is accepted, this is-apart from the well-known stele found in a dump at Megiddo (Fischer 1929:12-16; Kitchen 1986:299; Ritner 2009:218-219; Schipper 1999:129-132)—the second epigraphic evidence for pharaoh Sheshonq I unearthed in Cis- and Transjordan to date. ${ }^{16}$

Parallels: Closest to the scarab's inscription comes a museum item from Cairo: Inv.-No. CG 36297, which is featuring $h d-h p r-\left(R^{`}\right)$ stp.n-(J)mn-R' along with the prenomen and epithet $\check{s} \breve{s}(n q) m r j J m n-R$ " «Sheshonq beloved of Amun-Re» on its base (Petrie 1889:Pl. 56, $1775=$ Newberry 1907:Pl. 5,36297). ${ }^{17}$

Dating: A production date during the reign of Sheshonq I (946/45-925/924 BCE) may be assumed.

\section{Cat. No. 7: Scarab-Walking Sphinx or Griffin (Figure 11.7)}

Registration Details and Context: Khirbat en-Nahas خربة النحاس , Season 2002, Area S, Locus 330, Basket 6974, EDM 71241. During the first large-scale excavations at Khirbat en-Nahas in 2002, a number of Egyptian amulets were discovered in a small building in Area S, situated near the center of the site. The small four-room structure (see Chapter 2, this volume) was 
dedicated to processing slag with the aim of crushing this viscous material to retrieve any copper prills left in the slag from smelting activities. Ethnoarchaeological data related to recycling procedures in association with traditional metal production are described by Levy et al. (2008:83-95). The scarab described here was found in the western site of Room 4 in the lower level fill that was sieved. It is interesting that a small building with no evidence of prestigious occupants was associated with an imported Egyptian amulet (Levy, Adams, and Muniz 2004; Levy, Najjar, van der Plicht, et al. 2005).

Object: Scarab. Condition: The item is very worn, and the upper third of the plinth is broken off. Engraving: Hollowed-out engraving. Material: Enstatite. Color: Creamy light brown. Dimensions: $12.9 \times 9.6 \times 6.6 \mathrm{~mm}$.
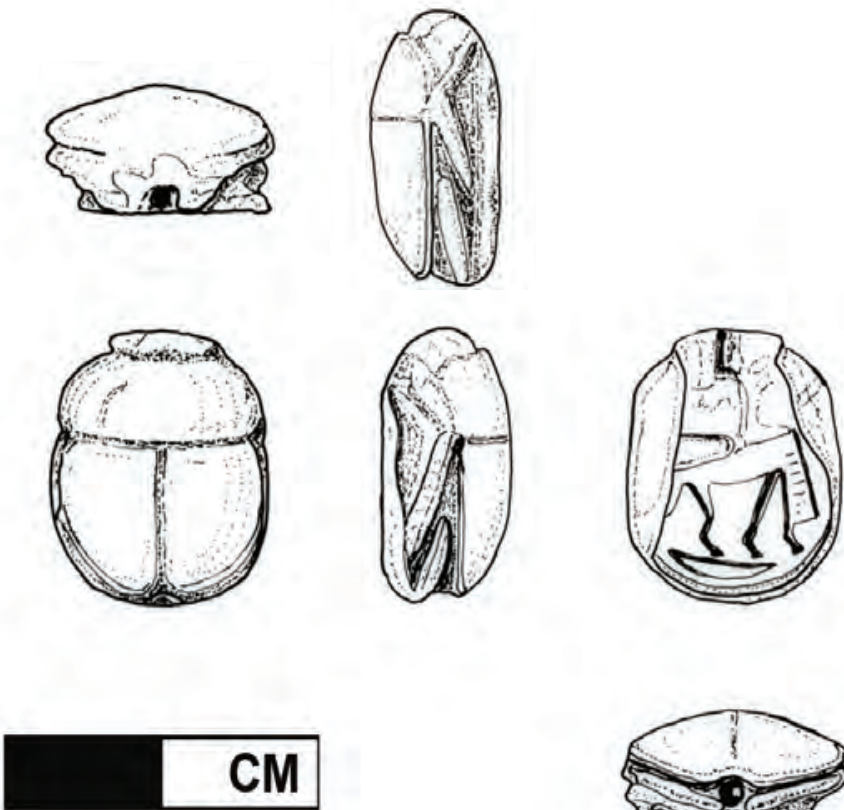

\section{CM}
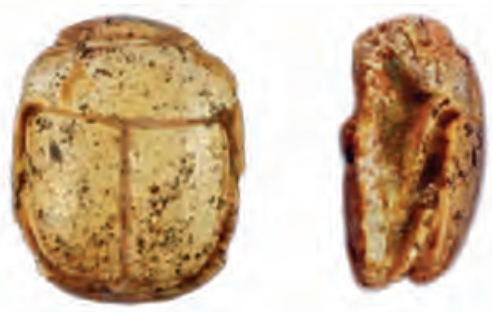

Figure 11.7 Scarab-walking sphinx or griffin, Khirbat en-Nahas, Area S, EDM 71241, L330, B6274.
Base: Sphinx or griffin ${ }^{18}$ (Keel 1995:\$543-552) dressed in a kilt striding to the right above a $n b(\mathrm{~V} 30$; Keel 1995:\$458) that serves as an exergue.

Discussion: Sphinxes or griffins are a commonnormally horizontally arranged-motif in the Late Bronze Age iconographic repertoire (cf. Lalkin 2008:Nos. 343-403). Eggler and Keel rightly note that-if vertically arranged on a seal's base-these heraldic beasts regularly stride above an enemy stretched on the floor. ${ }^{19}$ Furthermore, they add that the present item from Khirbat en-Nahas is stylistically closer to epigraphic seals from the Iron Age II (Eggler and Keel 2006:126 with many references; for an anepigraphic item dating to the Iron Age II, see, e.g., Achsib, Tomb 69: Keel 1997:68-69, No. 140).

Parallels: A sphinx passant above a $n b$ is found in vertical arrangement on the base of a scarab in the British Museum (Hall 1913:97, No. 998) and on an item from the former Matouk collection in the Bible+Orient Museum in Fribourg/Switzerland (Matouk 1977:384, No. 587). ${ }^{20}$

Dating: Eighteenth to nineteenth Egyptian dynasty (1539/30-1190 BCE) or later.

Bibliography: (Levy, Adams, Najjar, et al. 2004:874875) and Eggler and Keel (2006: Chirbat an-Nuhas No. 2).

\section{Cat. No. 8: Scarab-Hunting Scene}

(Figure 11.8)

Registration Details and Context: Khirbat en-Nahas خربة النحاس , Season 2002, Area S, Locus 316, Basket 6438, EDM 10243. This scarab was also discovered during sieving activities carried out for Room 4 in the Area S building at Khirbat en-Nahas. Unlike the other scarab (No. 7 above), this one was found in the upper levels of the room, suggesting that the entire room was disturbed in antiquity, perhaps by the final users of this part of Khirbat en-Nahas who used the last vestiges of this building as an animal pen.

Object: Scarab; typologically belonging to Group C of the EIAMS (cf. Münger 2005:394 with examples). Condition: The item is worn and damaged along the right flange of the plinth. Engraving: Bold linear and hollowed-out engraving. Material: Enstatite. Color: Yellowish light brown with traces of yellowish golden glaze. Dimensions: $16.1 \times 12.2 \times 9.2 \mathrm{~mm}$.

Base: The base is horizontally arranged with an archer standing to the right aiming toward a resting ibex (above; for the identification, cf. Keel in Keel et 
al. 1990:280-282) and a pacing lion (below). To the far right is a hardly visible standing human figure, probably facing toward the beholder.

Discussion: This hunting scene with a hunter chasing wild animals and attacking enemies ${ }^{21}$ is a typical motif within the EIAMS iconographic repertoire (motif group HS2a; cf. Münger 2011:137 with parallels from Egypt and Greater Syria in notes xvii and xviii), whose origins go back to the Ramesside iconography of the nineteenth and twentieth Egyptian dynasties (ca. 1292-1070/1069 BCE; for an outline of the long tradition of this motif, cf. Keel in Keel et al. 1990:288-291 with Figure 0130).

Parallels: Nearly identical items have been found in the southern Levant in contexts such as Beth Shean, Lower V (Keel 2010a:128-129, No. 66) and Tell elFar'ah South, Tombs 133 and 506 (Keel 2010b:120-

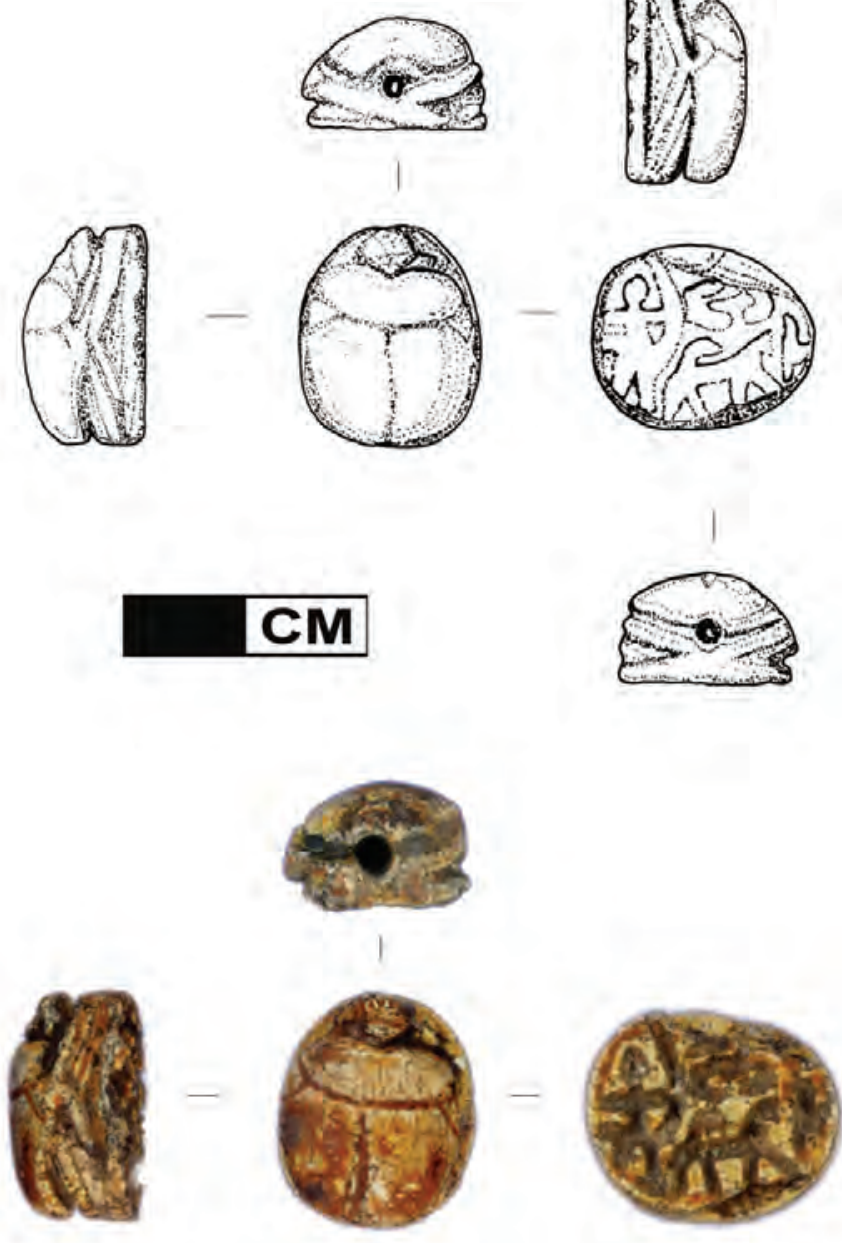

Figure 11.8 Scarab-hunting scene, Khirbat en-Nahas, Area S, EDM 10243, L316, B6438.
121, No. 216 and 136-137, No. 250). One item has been found on the surface at ${ }^{\circ}$ Tell el-Fukhar (Acco): Keel (1997:560-561, No. 87); see also "Tell el-Far'ah South (Keel 2010b:190-191, No. 378) "Gezer (Münger 2011:165) (catalogue entry Gezer 3 [previously unpublished]), and "Tell Jemmeh (Münger 2005:Pl. 23.7,40).

Dating: Around 960-900/880 BCE (see Cat. No. 1, above).

Bibliography: Levy et al. (Levy, Adams, Najjar, et al. 2004:874-875); Eggler and Keel (2006: Chirbat an-Nuhas No. 1); Levy and Najjar (2006:35); Levy et al. (2007:20-21 with Fig. 5); and Münger (2011:173 [catalogue entry Khirbat en-Nahas 1] with Pl. 47,1).

\section{Cat. No. 9: Aegis Amulet (Figure 11.9)}

Registration Details and Context: Khirbat en-Nahas خرية النحاس , Season 2006, Area M, Locus 635, Basket 9306, EDM 90464. The aegis amulet was found in Room 1 located in Area M at Khirbat en-Nahas. The room is part of four-room building complex constructed at the end of the tenth to the beginning of the ninth century BCE. A series of four rooms surround a courtyard (labeled "Room 3" in Figure 2.66). Room 1 is located in the most southerly aspect of the building complex. The fourth room was not excavated and is embedded in the eastern section of the Area M excavation. During the course of the excavation, Room 1 was dismantled so that excavations could be carried out to virgin soil in the area. The aegis amulet described below was found embedded in a beaten earth floor in Layer M2b along with many date seeds. One date seed was analyzed with radiocarbon dating, which yielded a date of 1020 to 911 BCE (2 sigma; Table 2.9 in Chapter 2, this volume).

Object: Aegis (amulet with broad collar, usually with a lion's head identifying the figure as Bastet or Sachmet); compare with Petrie (1914:42 with Pl. 35.195a-n) and Herrmann (1994:188-196, 219-222). The object is very worn. A high, possibly two-storied "hat" with a "button-shaped" top (usually interpreted as a double crown) is visible. The facial features are not visible anymore. The coiffure is barely traceable. It might be a wig with two braids. The broad collaroriginally decorated with rows of small globules? and possibly other geometric motifs (representing pendants and beads)-is most characteristic for this type of amulet. Measurements: $2.8 \mathrm{~cm}(\mathrm{H}) \times 2.0 \mathrm{~cm}$ $(\max . \mathrm{W})$. This is slightly larger than the average size of such amulets. 
Material and Production Technique: According to the literature, the material used is usually composition (for a definition of the various types, see Keel 1995:\$392-402 and, more specifically, regarding amulets and including manufacturing technology, see Herrmann 1994:26-28, 2006:3-5). Amulets of this kind are generally made in a mold (cf., e.g., the model depicted in Herrmann 1985:No. 140).

Parallels: Comparanda come from contexts dating to the Iron Age IB through Iron Age IIB, including Tel el-Far'a South, Tomb 201 (Petrie 1930:Pl. 36,201 and Pl. 41,259 = Herrmann 1994:No. 173). Herrmann dates the item to the Iron Age IB (because of its porous material, the plain and unworked back, and for the reason that the drill-hole pierces the object itself, i.e., there is no suspension device; see also Herrmann's [1994] dating criteria on pp. 34-35). The find context is problematic, since the item comes from a mostly unstratified common grave with at least 122 individuals (Petrie 1930:11-13, Pls. 40-41.67; see also the overview in Laemmel 2003:48-49). "Gezer: Macalister (1912:332 with Pl. 210,56 = Herrmann 1994:No. 176). Herrmann dates the item to the Iron Age IIA at the latest. Megiddo, Stratum V (Lamon and Shipton 1939:Pl. 74,23 = Herrmann 1994:No. 175). The item was found together with a fragment of the same type of amulet (Lamon and Shipton 1939:Pl. 74,22 = Hermann 1994:No. 182). Unfortunately, from paved room L318 (in which the two items were found), nothing besides a bead (Lamon and Shipton 1939:Pl. 90,37) was published. The locus, however, seems to be well embedded into Stratum VA-IVB architecture (Lamon and Shipton 1939:Figure 6). Herrmann (1994:220) forgoes to date the two items. ${ }^{\circ}$ Megiddo: Herrmann (1994:No. 178). This, according to Herrmann, is an Iron Age IIB specimen, since it is made of a solid composition material and the suspension device is constructed as a discrete element; "Megiddo:
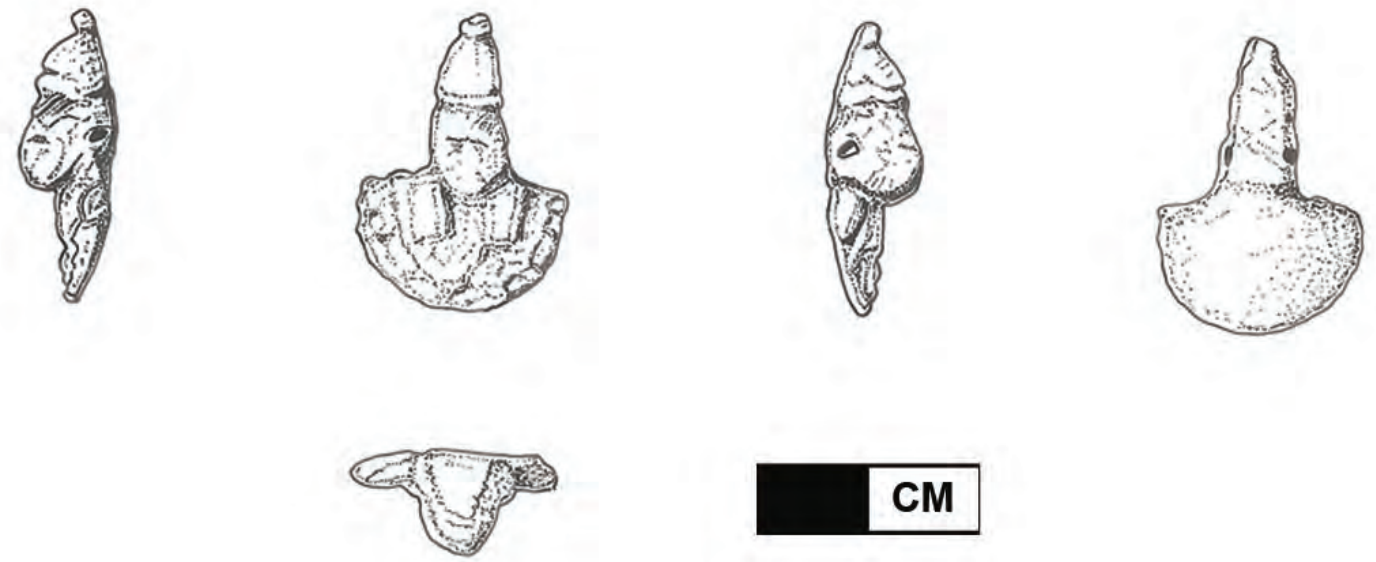

CM
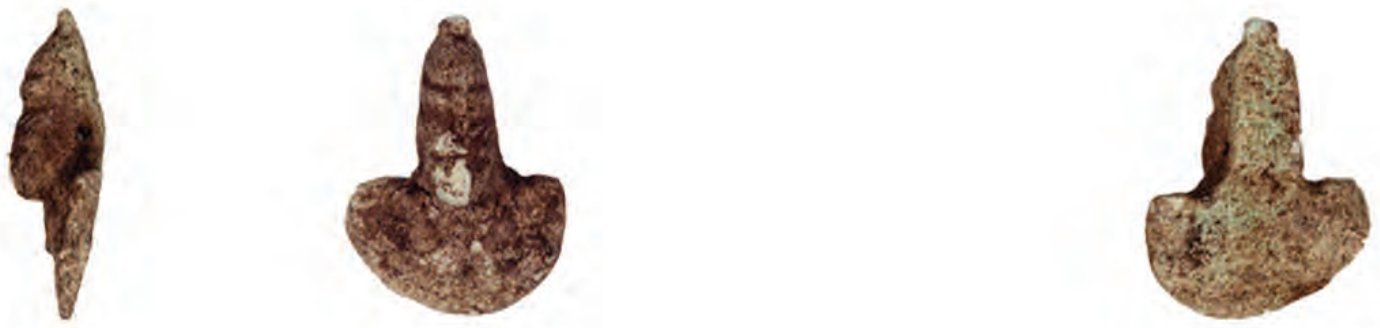

Figure 11.9 Aegis amulet, Khirbat en-Nahas, Area M, EDM 90464, L631, B9306. 
Lamon and Shipton (1939:Pl. 74,28 = Herrmann 1994:No. 174). Herrmann could not date the amulet more precisely than to the Iron Age IB to IIB. ${ }^{22}$

Three unfortunately unprovenanced objects, kept in the Bible+Orient Museum at Fribourg/Switzerland, are very similar in style to the item discussed here. They were published by Herrmann in 2003 as catalogue Nos. 213 to 215 and dated by him to the New Kingdom (1550-1070/69 BCE). These human-faced specimens are identified by Herrmann (2003:12) as representing the Egyptian goddess Mut.

Date: Petrie (1914) dated such objects to the twentysecond to twenty-fifth Egyptian dynasty (946/45-ca. 655 BCE). The dates attributed by Herrmann (1994) to this type of amulet range from the Iron Age I to the Iron Age IIB. However, given how the amulet was suspended and because the material used is rather porous, it is likely that, based on the aforementioned parallels, the amulet was produced sometime during the Iron Age IB or IIA.

\section{Cat. No. 10: Scarab-Striding Animal}

(Figure 11.10)

Registration Details and Context: Khirbat en-Nahas خرية النحاس , Season 2006, Area M, Locus 707, Basket 10118, EDM 91464. The "striding animal" scarab was found in Area M, also in the area of the fourroom building. The locus (L707, Layer M2a) where this amulet was found was also dated with a date seed to 970 to 838 BCE (see Table 2.9 in Chapter 2, this volume). Found at a higher elevation than the aegis amulet (No. 9, above) on a metallurgical working layer, there seems little doubt that this object was in use (worn as an ornament or as a seal) when Room 1 was occupied. The four-room building was closely linked to smelting activities carried out in Area M. This is evidenced by the continuous buildup of slag on the outside of the building, so much so that the doorway from Room 1 to the courtyard was intentionally blocked, suggesting that when metal production was carried out at an intensified scale, this room could no longer be occupied due to the extreme heat.

Object: Scarab; typologically belonging to Group B of the EIAMS (cf. Münger 2005:394 with examples; see also Cat. No. 1, above). Condition: Heavily worn; the plinth is damaged on the right-hand side. Engraving: Hollowed-out and bold linear engraving. Material: Enstatite. Color: Spotted reddish yellow. Dimensions: $13.1 \times 10.6 \times 7.1 \mathrm{~mm}$.
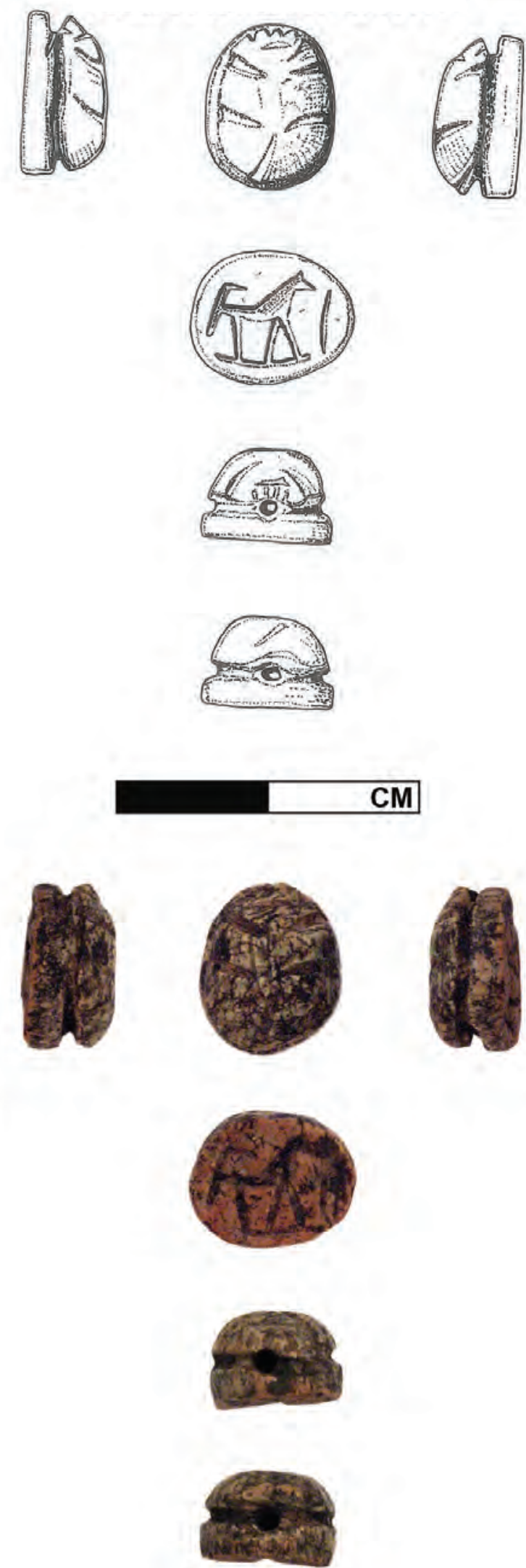

Figure 11.10 Scarab—striding animal, Khirbat en-Nahas, Area M, EDM 91464, L707, B10118. 
Base: The horizontally arranged plinth displays a quadruped with a raised and bent tail prancing on a vertical baseline to the right. In front of it is a vertical element.

Discussion: Striding animals like the one on the seal from Khirbat en-Nahas are usually interpreted as lions. ${ }^{23}$ Lions appear as the main motif on scarab bases already in the MB IIA and continue to be an important motif until the Persian period (Keel 1995:\$536-537 and references therein). The graphic style of the lion on this Khirbat enNahas scarab, however, is very typical for the EIAMS, where it is one of the main iconemes in the following motif groups: single lion striding to the right, lion walking over a human figure stretched out on the ground, or one or two lions (one atop the other) hunting prey and-in turn-being targeted by a human in various hunting scenes (Münger 2005:395 with Pl. 23.6 and 23.7 and 2011:137-139 with many references to parallels in Egypt, the Mediterranean, and Greater Syria). ${ }^{24}$ The vertical line to the right of the animal should be interpreted as a floral element or a branch. This is quite often the sole secondary element in single striding lion scenes beginning in the Middle and Late Bronze Age (Keel 1995:\$537; see also Münger 2011:138 motif groups LS1a-c).

Parallels: Single striding lions (often accompanied by a branch) occur in the EIAMS assemblage of the southern Levant well over 20 times. ${ }^{25}$ Well-stratified parallels were retrieved, for example, at Achzib, Tomb ZR1 (Keel 1997:26-27, No. 15 = Münger 2011: Achzib 1); Beth Shemesh, Tomb 1 (Keel 2010b:222-223, No. 12 = Münger 2011: Beth Šemeš 2); Tel Gerisa, Iron Age IIA context (Giveon 1988:68-69, No. 73 = Münger 2011: Tel Gerisa 2); and Tell es-Sa 'idiyeh, Tomb 65 (see Eggler and Keel 2006:374-375, No. 18 and Münger 2011: Tell es-Sacidiyeh 9).

Dating: Around 960 to $900 / 880$ BCE (see Cat. No. 1, above).

Bibliography: Levy et al. (2008:16462 and supporting information [SI] Fig. S1) and Münger (2011:173 [catalogue entry Khirbet en-Nahas 2] with Pl. 47,2).

\section{Cat. No. 11: Scarab-Flanking Red Crowns} (Figure 11.11)

Registration Details and Context: Khirbat en-Nahas خرية النحاس, Season 2009, Area R, Locus R09L053, Basket R09B0380, EDM R09F0475. The "flanking red crowns" scarab was found in the monumental building in Area $\mathrm{R}$ at Khirbat en-Nahas. The structure is the second largest building at the site (the fortress gatehouse is slightly larger). Situated in the center of the site, this tenth-century BCE building was contemporary with the fortress and probably served as an elite residence at Khirbat en-Nahas. As described in Chapter 2 (this volume), like many of the buildings at the site, the Area $\mathrm{R}$ building has rooms built around a central courtyard. One of these six rooms (the northwest one) contains a large stairwell that leads to a second floor. The presence of a "throne" or dais attached to the exterior of building, surrounded by a courtyard, along with numerous iron, ceramic, and trade items, points to the elite nature of this structure.

Object: Scarab; the simple back with the elytra indicated by single lines, the minimalist design of the head and the basic rendering of the legs point to a Late Bronze or even later date. Condition: Slightly chipped along the border of the plinth. Engraving: Crude linear and hollowed-out engraving. Material: Enstatite. Color: Creamy brown. Dimensions: $16.3 \times 11.6 \times 7.9 \mathrm{~mm}$.

Base: The plinth—with a framing line-is horizontally arranged and graphically separated into three vertical "panels": two schematically engraved red crowns ( $d$ šrt; S3; Keel 1995:\$452) are facing to the outside. In the
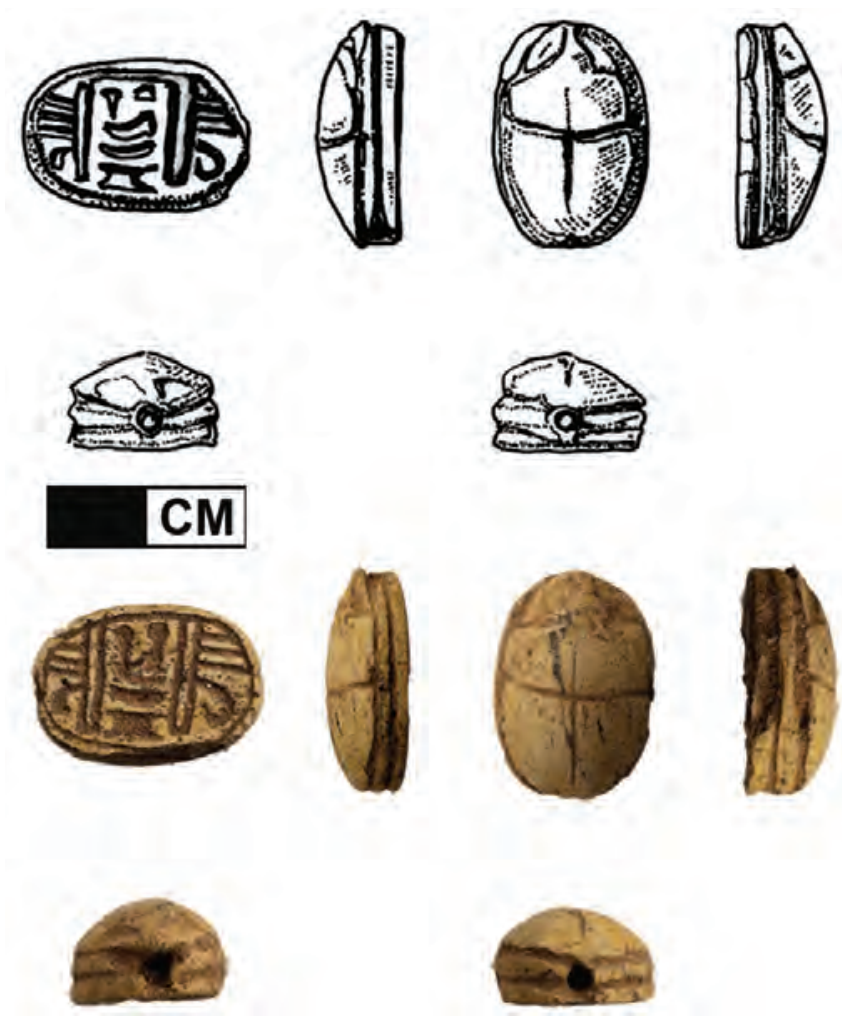

Figure 11.11 Scarab-flanking red crowns, Khirbat en-Nahas, EDM R09F0475, LR09L053, BR09B0380. 
center of the plinth are five almost undecipherable hieroglyphs in a row. They are (from top to bottom): mrj (N36; Keel 1995:\$457), $t$ (X1; Keel 1995:\463), $n$ (N35; Keel 1995:\$458), and $n t r r n f r$ (R8 and F35; Keel 1995: $\$ 460$ and 459).

Discussion: Similarly arranged addorsed red crowns flanking hieroglyphs are frequent during the Middle ${ }^{26}$ and the Late Bronze Age. ${ }^{27}$ The concept, however, reappears during the twenty-second Egyptian dynasty on very similarly executed scarabs, which are-like the present item-engraved in an archaizing linear style (cf., e.g., 'Beth Shean: Keel 2010b:180-181, No. 187; see also "Tell Jemmeh: Petrie 1928:Pl. 19,10). ${ }^{28}$

As for the hieroglyphs in the central panel, one may cautiously propose the reading $m r j . t-n-n \underline{t} r-n f r$ «beloved by the good god» (note that in this case, the original owner would have been a woman due to the feminine determinative).

A graphically comparable arrangement of the plinth-but with completely different signs-is, for example, an also stylistically analogous item from Tell el-Far'ah South, Tomb 936 (Keel 2010b:328-329, No. 702) (with the name of the god Ptah).

Parallels: Identically stylized red crowns, also with three vertical strokes but flanking a solitary $n f r$ can be seen on an item from "Ashkelon (Keel 1997:722-723, No. 87), ${ }^{29}$ which is in all aspects (including the shape of the amulet itself) very similar to the present item from Khirbat en-Nahas and dated by Keel to the twenty-second Egyptian dynasty (i.e., 946/945-ca. 735 BCE).

Dating: Due to the lack of well-stratified parallels, only a broad time frame can be proposed, that is, nineteenth to twenty-second Egyptian dynasties (1292-713 BCE), with a tendency toward the tenth and ninth centuries BCE.

\section{Cat. No. 12: Scarab-Winged Sun Disks}

(Figure 11.12)

Registration Details and Context: Khirbat en-Nahas خـربة النحاس , Season 2009, Area R, Locus R09L101, Basket R09B1308, EDM R09F1635. The scarab with "winged sun disks" is the second Egyptian scarab found in the Area $\mathrm{R}$ building. It was discovered in sediments between the entrances to Rooms 5 and 8, while sieving. A tiny chalk votive vessel was found in Room 5. There was also a paucity of artifacts in Room 8 , but it was associated with a well-crafted stone lintel. This scarab may be more securely dated by a suite of radiocarbon dates from inside the building (Table 2.19). A full discussion of the radiocarbon analysis is presented in Chapter 2 (this volume). Taking into consideration the problem of old wood, when the six calibrated radiocarbon dates are modeled with Bayesian analyses, the start date is between 1157 and 933 BCE $(66.6$ percent probability). While the winged sun disk scarabs range in date throughout the twenty-second Egyptian dynasty (946/945 - ca. 735 BCE), the radiocarbon dating evidence helps place the sample described here more securely in the mid-tenth century BCE. These remarks apply equally to Cat. No. 11 described above.

Object: Scarab. Condition: Worn; the plinth is partly damaged. Engraving: Linear and hollowed-out engraving. Material: Enstatite. Color: Yellowish brown with green glaze in the recesses. Dimensions: $14.5 \times$ $10.8 \times 5.9 \mathrm{~mm}$.

Base: Two confronted schematized winged sun disks (Keel 1995:\$450)—each with two uraei hanging down-flanking an oval inscribed with $m n$ - $h p r-r^{6}$, the throne name of Thutmose III (1479-1425 BCE; cf. Keel 1995: $\$ 634.650 .663)$.

Discussion: The well-known motif on the scarab's base (Jaeger 1982:\$346) is one of the many examples of posthumous veneration of the legendary Egyptian pharaoh of the eighteenth dynasty.
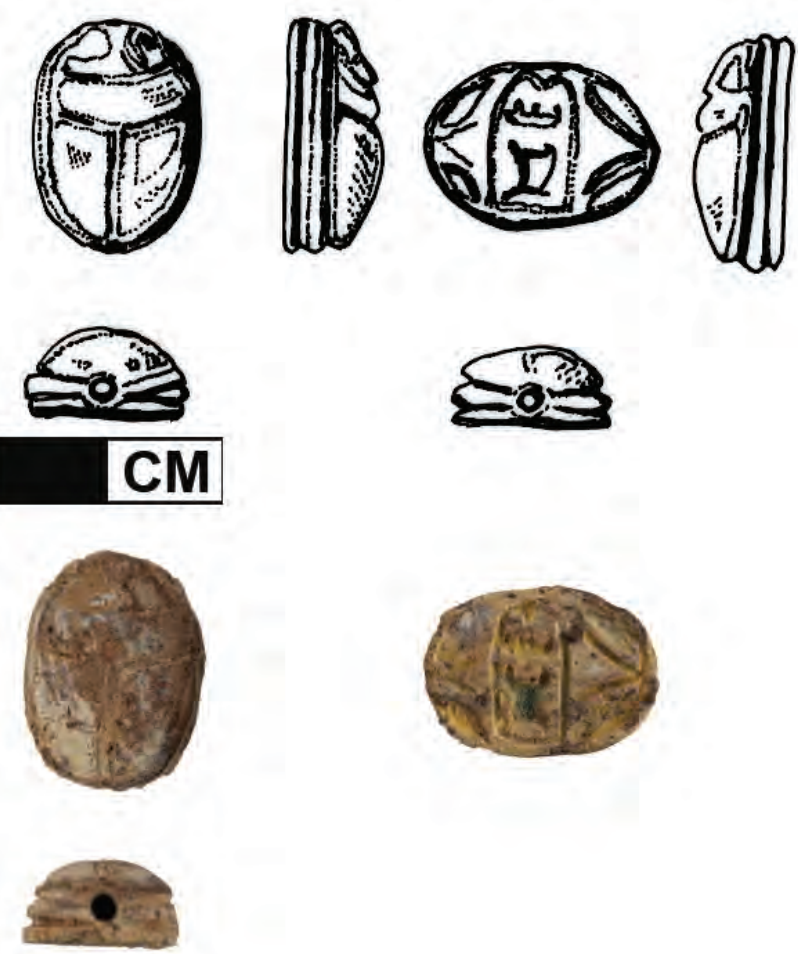

Figure 11.12 Scarab-winged sun disks, Khirbat en-Nahas, Area R, EDM R09F1635, LR09L101, BR09B1308. 
Parallels: The following items from the southern Levant feature the same base engraving: ${ }^{\circ} \mathrm{Tell}$ el-Fukhar (Acco) (Keel 1997:548-549, Nos. 51 and 52); Ashdod, Byzantine refuse pit (Keel 1997:686-687, No. 66); Beth Shean (Keel 2010a:180-181, No. 187); Tel Halif, Iron Age II burial cave (Giveon in Biran and Gophna 1970:168 Pl. 38C (1)); and "Samaria (Reisner et al. 1924:Pl. 56,e3).

Dating: Twenty-second Egyptian dynasty (946/945ca. 735 BCE).

\section{Cat. No. 13: Scarab-Standing Falcon with "Ankh Sign" (Figure 11.13)}

Registration Details and Context: Khirbat en-Nahas خرية النحاس , Season 2009, Area W, Locus W09L098, Basket W09B0522, EDM W09F0875. Four Egyptian amulets were found in Area W, located in the southernmost occupation area at Khirbat en-Nahas. Area W consists of three room complexes comprising a total of 18 rooms (see Chapter 2, this volume). A variety of activities took place in these building complexes, including storage, ritual, and domestic. The scarab with "standing falcon with ankh sign" was found while sieving material from L98, a Stratum W1b locus in Courtyard 1 of Area W. Stratum W1b was identified as a "post-abandonment" phase, just beneath topsoil and wall collapse, primarily representing sporadic reuse in the Classical, Late Antique, or Islamic period. This locus in particular seems to contain fairly mixed material, including pottery (Iron Age bowl, BL35 Type 2) that has been identified as being potentially tenth century (see Chapter 4 , this volume). Thus, this scarab seems to be in this locus as a result of post-Iron Age mixing of material from the earlier, stratified Iron Age deposits in this area.

Object: Scarab. Condition: The abraded plinth is especially damaged along the ridge; the back is partially chipped off. Engraving: Linear and hollowedout engraving. Material: Enstatite. Color: Yellowish brown. Dimensions: $17.3 \times 12.9 \times " 6.2 \mathrm{~mm}$.

Base: The plinth is horizontally arranged and bordered by an only partially preserved line. It is dominated by a falcon (G6; Keel 1995: $\$ 442.450 .556)$ facing to the right. To its right is a quite elaborately engraved ' $n h$, the symbol of life (S34; Keel 1995: $\$ 449)$. Above the falcon's back is a short inscription with a $\underline{d}$ (I10)—a wriggling cobra partly framing the other signs-and a $t(\mathrm{X} 1$; Keel 1995:\$463). Below the $t$ is a short horizontal line $\left(\mathrm{a} n b^{\text {? }}\right)$, followed by a $r^{\circ}$ (N5; Keel 1995:\$461) with three determinative strokes (Z2). At the bottom might be a $n b$ (Keel 1995:\$458).
Discussion: An ankh sign in front of a standing falcon is not unusual on Late Bronze Age scarabs (but the elements above its back differ and do not normally follow a standard iconographic pattern). ${ }^{30}$

Parallels: A very close parallel was found on the surface of ${ }^{\circ}$ Tell el-Fukhar (Acco) (Keel 1997:552-553, No. 66; see parallels from Egypt and museum collections there). It features (although vertically arranged) most of the iconographic elements mentioned above, and the base can similarly be read as «Re-Harachte, who lives eternally, my Lord». This may be a later variant of the original epithet $d j$ ' $n h \underline{d} d t$ (D37, I10, S34), meaning "gifted of life in eternity», which is also found on Late Bronze Age items from "Tell el-'Ajjul (Keel 1997:No. 202) (together with the throne name of Amenophis II, 1428-1397 BCE) and Lachish, Fosse Temple (Tufnell et al. 1940:Pl. 32A/B,3) (together with the throne name of Amenophis III, 1388-1351 BCE); Tomb 4004 (Tufnell 1958:Pl. 37/38,284); and another one found on the surface (Keel 2004:No. 24) (both together with the throne name of Thutmose IV, 1497-1388 BCE). ${ }^{31}$

Dating: In view of the scarab type, the engraving style, and the aforementioned parallels, the item should be
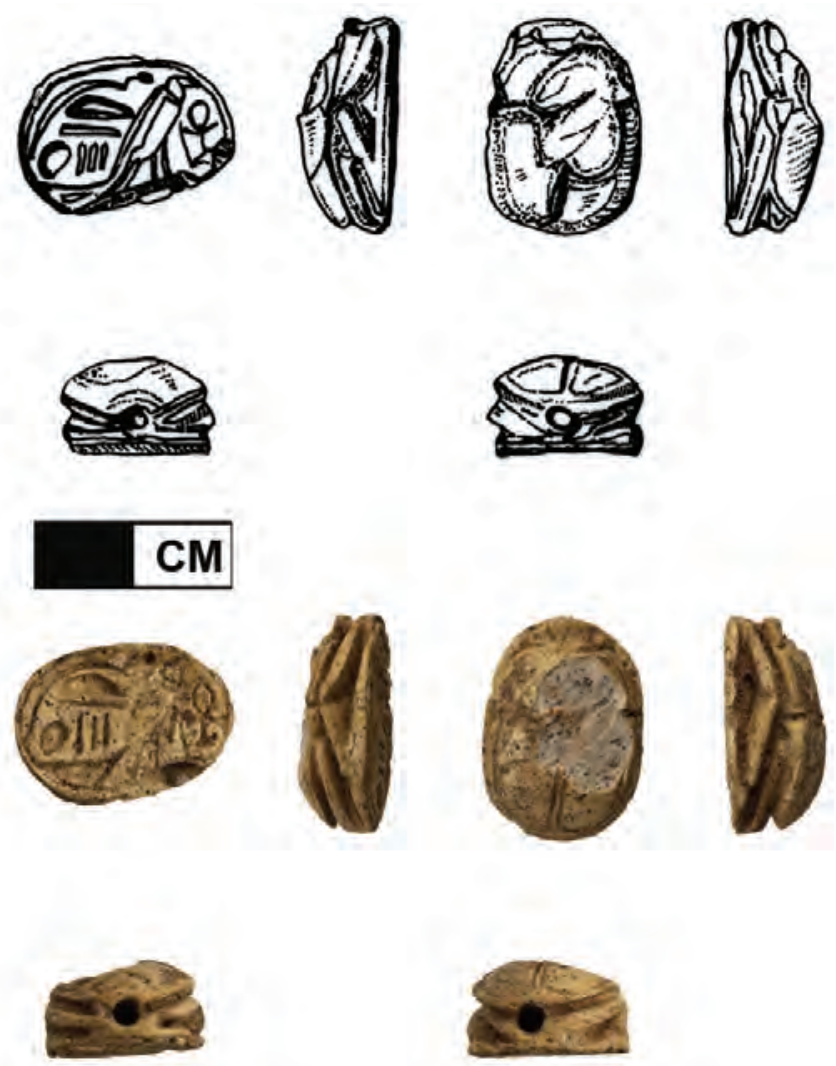

Figure 11.13 Scarab-Standing Falcon with ankh-sign, Khirbat en-Nahas, Area W, W09F0875, LW09L098, BW09B0522. 
dated to the Ramesside period, that is, the nineteenth and twentieth Egyptian dynasties (ca. 1292-1070/1069 BCE).

\section{Cat. No. 14: Pataikos (Figure 11.14)}

Registration Details and Context: Khirbat en-Nahas خرية النحاس, Season 2009, Area W, Locus W09L124, Basket W09B1045, EDM W09F1370. The Pataikos amulet described below was found in Structure 2, Room 8. In nearby Room 7, a large standing stone was erected in the middle of two large pillars (see Chapter 2, this volume), suggesting ritual space was created here. The Pataikos was found in the upper levels of Room 8 in a W2AI fill. In addition to this amulet, beads and a pithos (type 5) storage vessel was found here (see Chapter 5, this volume, for a discussion of the ceramics).

Object: Torso of a three-dimensionally modeled pataikos (see, e.g., Arav and Bernett 1997 for an overview on this type of amulet). The well-fed naked figure has a short penis; the arms are resting on the belly. Measurements: "1.6 (H) $\times 1.1(\max . \mathrm{W}) \times 0.8 \mathrm{~cm}$ (max. D).

Material and Production Technique: Whitish composition; coated with light bluish green glaze; mold-made (see also Cat. No. 9, above).

Parallels: A very similar pataikos has been unearthed at Tel Dalhamiya in an Iron Age II context (Herrmann 2006:No. 164), which is dated by Herrmann (2006:129) to the Iron Age IIB.

Date: On the basis of the parallel from Tel Dalhamiya, an Iron Age IIB date is suggested.

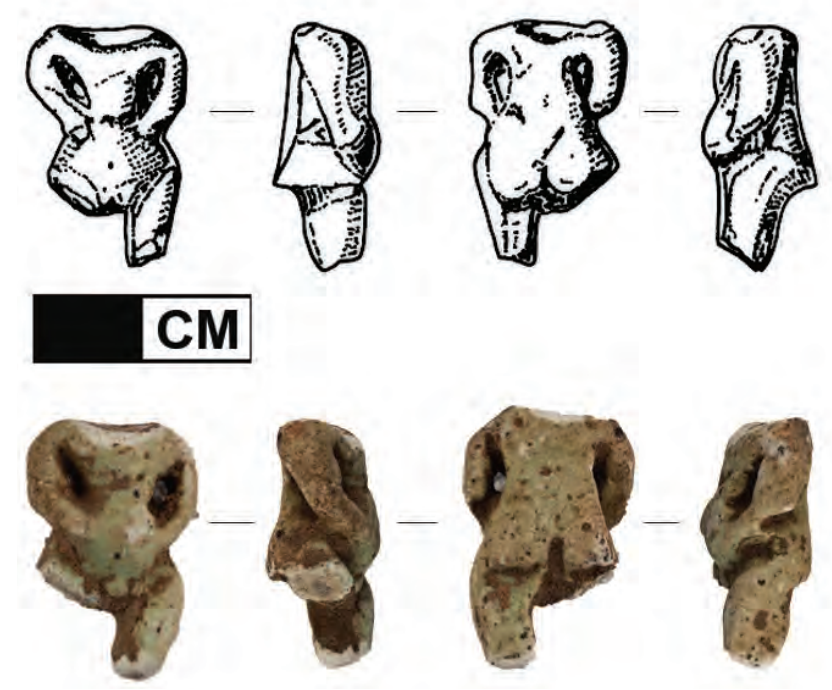

Figure 11.14 Pataikos, figurine Khirbat en-Nahas, Area W, EDM W09F1370, LW09L124, BW09B1045.

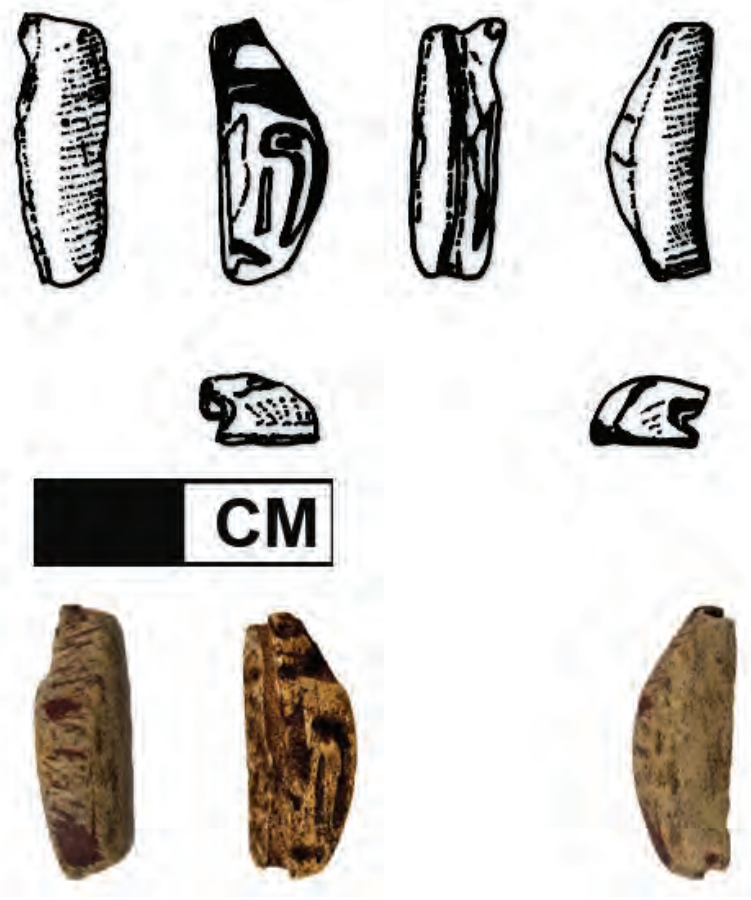

Figure 11.15 Cowroid?, Khirbat en-Nahas, Area W, EDM W09F1837, LW09L178, BW09B1472.

\section{Cat. No. 15: Cowroid? (Figure 11.15)}

Registration Details and Context: Khirbat en-Nahas خربة النحاس, Season 2009, Area W, Locus W09L178, Basket W09B1472, EDM W09F1837. The third Egyptian amulet found in Area W is a broken cowroid. It was found in the courtyard of Structure 2, where Room 8 borders its northern side. This structure has been interpreted as having had some ritual function (see Chapter 2, this volume).

Object: Cowroid?, that is, a Egyptian seal type imitating a cowrie shell (type I; Keel 1995:\$184-188).

Condition: The stamp-seal amulet is broken along the drilling, and less than 50 percent of the original item is preserved. Engraving: Bold linear engraving.

Material: Enstatite (field ID). Color: Medium brown with reddish brown coating (field ID). Dimensions: $14.4 \times$ × $5.6 \times 6.4 \mathrm{~mm}$.

Base: The base is undecipherable. However, it should be noted that cowroids were-due to their resemblance to female genitalia-symbolically connected to female fertility (Keel 1995:\$184).

Dating: According to the proportions of the presumed seal type, a Late Bronze Age date is suggested (ca. 1500-1300 BCE). 
Cat. No. 16: Scarab (Figure 11.16)

Registration Details and Context: Khirbat en-Nahas خربة النحاس , Season 2009, Area W, Locus W09L187, Basket W09B1860, EDM W09F2254. The fourth Egyptian amulet from Area $\mathrm{W}$ is a chipped scarab found in Room 13 of Structure 3-the most western complex. It was found in a W2AI fill along with Midianite ware, a bowl, jug, and krater (see Chapter 5, for ceramic discussion). The location of this room near other domestic facilities suggests that the Structure 3 complex was a residence. The fact that four Egyptian amulet imports were found in Area W suggests that the residents were more than simple workers at the site and retained some higher social status.

Object: Scarab. Condition: The back has several large chips, and the base is damaged along the right edge of the plinth; worn. Engraving: Bold linear and hollowed-out engraving. Material: Enstatite. Color: Light to medium brown. Dimensions: $16.3 \times 11.6 \times$ $7.9 \mathrm{~mm}$.

Base: The plinth is vertically arranged. It displays in the lower part two antithetic uraei (Keel 1995:\$522523) flanking a $d d$-pillar (Keel 1995:\$451). The upper part of the plinth is engraved with a lying lion (Keel 1995:\$536-537) facing to the right; above its back is a roundish/oval element ( $r$ N5; Keel 1995:\$461) and a vertical stroke ( $n^{3}$; N35; Keel 1995: 4458$)$.

Discussion: The combination of $\underline{d} d$-pillar flanked by two uraei as the sole motif is found on an early New Kingdom item at Lachish, Fosse Temple (Tufnell et al. 1940:Pl. 32,23) and combined with $m n-h p r-r^{c}$, the throne name of Thutmose III (1479-1425 BCE), at "Gurob (Brunton and Engelbach 1927:Pl. 25,25) (see also an item kept at Cairo: Newberry 1907:Pl. 2,36108) and Gezer, Tomb 56 (= Strata XVII-XIV, cf. Dever 1974:4) (Macalister 1912:Pl. 80,26), which are equally dated to the eighteenth Egyptian dynasty (cf. Jaeger 1982:\$1001-1003). In combination with other signs, the motif group is found, for example, on later items dated to the nineteenth Egyptian dynasty from Tell el-Far'ah South, Tomb 981 (Keel 2010b:348-349, No. 756) (combined with a bark and a moon sign above; see also another item from this site with unknown context, which is combined with a Tilapia fish: Keel 2010b:376-377, No. 824); ${ }^{\circ}$ Shiloh (Brandl 1993b:215, No. 13) (combined with a winged sun disk and an $m n$ ); and Tell es-Sa'idiyeh, Tomb 240 (Eggler and Keel 2006:376-377, No. 22) (combined with two $n b$ ).
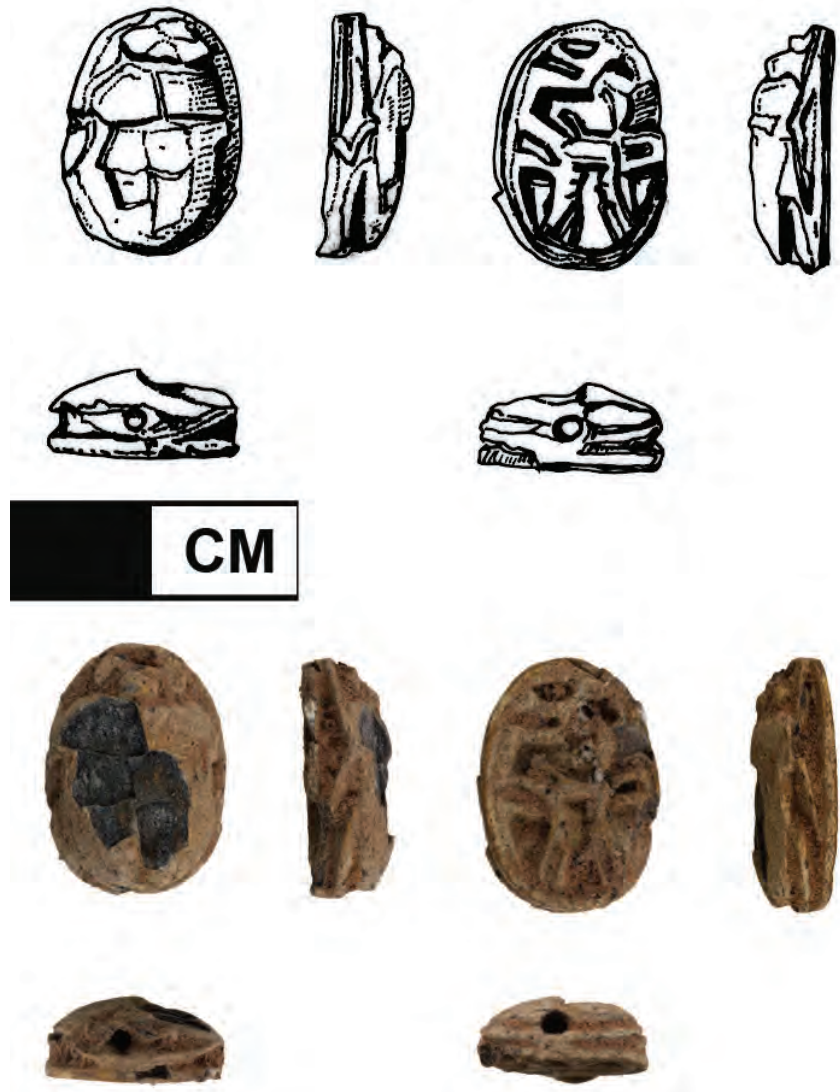

Figure 11.16 Scarab, Khirbat en-Nahas, EDM W09F2254, LW09L187, BW09B1860.

The reclining lion ${ }^{32}$ in combination with $n b$ and $r^{\text {c is, }}$ for example, found on a Late Bronze Age item found at ${ }^{\circ}$ Tell el-Fukhar (Acco) (Keel 1997:558-559, No. 78) (with further parallels; see also Tell el-Far'ah South, Tomb 984: Keel 2010b:372-373 and 408-409, No. 909, for an item without context). Lion, $n b$, and sun disk can be read as the divine name Amun- $\mathrm{R}^{\text {' (Jaeger }}$ 1982:294, note 218; Keel 1995:\$642-443).

Parallels: No exact parallels could be found, but see above for comparable base engravings.

Dating: Nineteenth to twentieth Egyptian dynasties (1292-1070/69 BCE).

\section{Conclusions}

The small assemblage of Egyptian amulets found at four different Iron Age sites investigated by the UCSDDOAJ ELRAP team provides a small but important window on the nature of Egyptian-Edom interaction during this period. All but one of these finds came from stratified excavations. The exception is actually the most important Egyptian discovery made to date in 
southern Jordan and perhaps in the southern Levant for the Third Intermediate period. This is a scarab bearing the name of Shoshonq I found on the surface of the mostly Early Bronze III to IV copper production site of Khirbat Hamra Ifdan. As noted above, while there is no evidence of Iron Age buildings at the site, there are important remains of tenth-century BCE copper smelting activities (Ben-Yosef et al. 2010; Levy et al. 2012). The disruption of metallurgical activities at Khirbat en-Nahas recorded in a deep sounding at one of the slag mounds at the site was attributed by Levy et al. (2008) to agents from the Shoshenq I campaign in the southern Levant, around 925 BCE. According to Kitchen (2003:470), a "flying column" from Shoshenq I's forces made their way across the northern Negev, to the south end of the Dead Sea and south through the Wadi Arabah. The "gateway" to the Faynan copper ore region from the west is through the Wadi Fidan, which cuts through the Jabal Hamrat Fidan where Khirbat Hamra Ifdan (KHI) is situated. It is possible that someone carrying the Shoshenq I scarab seal dropped it at the site during this march.

About $1 \mathrm{~km}$ to the north of KHI, the Iron Age cemetery of Wadi Fidan 40 is situated. Here two Egyptian amulets were found that attest to social interaction between the nomadic population buried there and Egypt from the Middle Bronze IIB through the Iron IIB periods. The earliest stamp-seal amulet in the present assemblage dates to the early MB IIB period and was found in an Iron Age tomb at Wadi Fidan Cemetery 40 (Cat. No. 4). It may be considered an heirloom or an indicator for later import of Egyptian goods, indicating exchange between the local population and Egypt, perhaps reaching back many centuries before its final deposition at this burial place.

However, the bulk of amulets date to the close of the Iron Age I and the beginning of the Iron Age IIA (Cat. Nos. 2, 5-6, and 8-12). Other items that belong to the immediate preceding period complement this evidence, which is the norm (Cat Nos. 3, 7, 13, and 15-16). ${ }^{33}$ Only one item may be chronologically positioned in the Iron Age IIB (Cat. No. 14); later seal and amulet types are missing. This not only reflects a peak of activity during the Iron Age I and the Iron Age IIA in the area but also indicates intensive contacts between, for example, the copper production center at Khirbat en-Nahas, where most of the material comes from $(n=10)$, and the Egyptian realm. These links are especially well illustrated by the presence of items belonging to the EIAMS, which were most probably produced during the reigns of pharaohs Siamun and Sheshonq I and somewhat thereafter (ca. 980-900 BCE) in the Eastern Delta in Lower Egypt (Münger 2003, 2005) and are further corroborated by the presence of typical Egyptian amulet types like an aegis (Cat. No. 9) found well embedded in a context relating to melting processes at Khirbat en-Nahas.

Some Egyptian involvement in the mining activities in the Faynan region during the middle years of the tenth century BCE may further be cautiously claimed on the basis of the highly important find of a scarab bearing the throne name Sheshonq I (946/45-925/924 BCE). Although found on the surface of Khirbat Hamra Ifdan, where Iron Age IIA smelting activities did take place (Levy et al. 2012; see Chapter 13, this volume), it nevertheless provides the second material reference ever found in Cis- and Transjordan to this pharaoh, well known from Egyptian sources (Jansen-Winkeln 2007:137; Ritner 2009:173-228) and biblical texts (1 Kings 11:40, 14:25-26 and 2 Chronicles 12:2-9). The first came from the University of Chicago's excavations at Megiddo, where part of a monumental stele was found bearing Sheshonq I's birth and throne name (Fischer 1929:12-16). At this point in our research, it is difficult to clarify the exact nature of Egyptian involvement in tenth-century BCE mining and metallurgy activities in Faynan. However, this find and others from the Third Intermediate period add weight to the earlier suggestion that metal production was disrupted by Sheshonq I's forces at Khirbat en-Nahas (see Levy et al. 2008:16465) and that they were present in the Faynan region for some period. What exactly happened in sociopolitical terms after copper production was disrupted in the early tenth century BCE remains an open question.

\section{Acknowledgments}

We thank Barbara Hufft (University of Bern), Prof. Joachim F. Quack (Heidelberg University), and Prof. Bernd U. Schipper (Humboldt University of Berlin) for their advice on Egyptological matters and Dr. Abigail Limmer (University of Arizona) for her valuable comments on an earlier draft of this chapter. Needless to say, all remaining mistakes and errors are the authors' sole responsibility. Thanks also go to Caroline Hebron, UCSD ELRAP, for the illustrations presented here, and to Ulrike Zurkinden, Fribourg, for her drawing of Fig. 11.6. 


\section{Notes}

1 The head type of Group B corresponds to Type E2 of Eggler and Keel (2006:XVI).

2 Enstatite denominates steatite-a silicate mineral that is foreign to the southern Levant-transformed and considerably hardened through heat (Keel 1995:\$383390).

3 The horizontal line does not form a perpendicular angle with the vertical stroke to the right, like, for example, on an item allegedly found at "Tel Deir el-Balah (Keel 2010a:438-439, No. 95); for an explanation of this phenomenon, see Keel (2010a:418, No. 43).

4 To the best of this writer's knowledge, $h^{\circ}(j)$ never occurs together with the written name of Amun on scarab bases, even if it is strongly connected to the sun god (Hornung and Staehelin 1976:169).

5 Compare with Münger (2011:137) with additional examples from Egypt in note ix and catalogue entries ${ }^{\circ}$ Acco [Tell el-Fukhar] 24, el-Ahwat 1 [main phase], -Aphek 3, Aškelon 5-6 [Iron Age II contexts], Dor 4 and 6 [local strata G-7a and G-6/5], Tell el-Far'ah (S) 20 and 22 [Tombs 210 and 510], and ${ }^{\circ}$ Megiddo 21.

6 Note that it could also be a secondary $m n$.

7 Note that at least one $r^{6}$ would be expected at this position.

8 Note that the objections of Singer-Avitz (2008:76-77) toward the dating of the Kadesh Barnea seals lack any sound basis and are the result of a truncated rendering of citations; see also (Münger 2009:124, note 40).

9 Furthermore, a similar composition with a uraeus flanked by two $n f r$ is, for example, found on the lower part of the plinth of a scarab unearthed at Tell el-'Ajjul, Tomb 1410B (Keel 1997:206-207, No. 309) (in the upper part of the plinth, a red crown is flanked by two $m 3^{*} t$ feathers; for a comparable iconography see also Tell el-Far'ah South, Tomb 574: Keel 2010b:104-105, No. 176).

10 Listed by Petrie as coming from Tomb 504; for a correction of this attribution, see Braunstein (1998:506).

11 An equally "rectangular piece with a sheaf shaped handle" bearing a somewhat similar base engraving is Basel: von Bissing collection (Hornung and Staehelin 1976:No. 588).

12 For a dismissal of hitherto proposed readings of Pharaonic names on such seals' bases, compare with Jaeger (1982:\$1048) and Keel (1995:\$212).

13 For a critique of the early dating of the Early Iron Age cemeteries and the corresponding Stratum XII at Tell es-
Sa'idiyeh, compare with Münger (2003:75 with further references). An item from Megiddo (Loud 1948:146 with Pl. 162,9) was associated by its excavators with Stratum VII. Yet, they did not rule out a somewhat later date of the find spot. For another outlier from Tell Jemmeh, compare with Keel (1995:\$213).

14 But see Ben-Yosef (2010:571-575).

15 Alternatively, one might consider an identification with Smendes, the founder of the twenty-first Egyptian dynasty (1070/1069-1044/43 BCE); Takelot I (ca. 890-877 BCE); Sheshonq IIIa (ca. 798-785? BCE); or Takelot II (841-816 BCE). This is less likely, since for these rulers, only the throne name $h \underline{d}-h p r-R^{\prime}$ stp. $n-R^{\star}$ is attested (von Beckerath 1999:178-179, 186-187, 190-193) and only for Sheshonq I is either $h \underline{d}-h p r-R^{\prime}$ stp.n-R* or $h \underline{d}-h p r-R^{\prime}$ stp.n-(J)mn documented (Jansen-Winkeln 2007:1-29; but see Dodson 1993 for the possibility that $h d-h p r-R^{\prime}$ stp.n(J) $m n$ is attested for Sheshonq IIIa as well). Furthermore, it should be noted that the combination of $(J) m n$ and $R^{\prime}$ together with $h \underline{d}-h p r-R$ ', like on the present item, is currently not attested in the available epigraphic corpus.

16 Note that Keel speculates about an allusion to Sheshonq's throne name on a scarab found at Achsib, Tomb ZR 28 (Keel 1997:34-35, No. 37); for the hypothesis that Sheshonq's name is preserved on Middle Iron Age bone seals, compare with Keel and Uehlinger (1998:536-537).

17 For the peculiar position of the sun disk, compare with, for example, Petrie (1889:Nos. 1764, 17671768, 1773).

18 Due to the damage to the plinth, no differentiation can be made.

19 They give as examples Tell el-Ajjul, Tomb 1116 (Keel 1997:192-193, No. 266) (= Lalkin 2008:No. 389) and Lachish, Tomb 4004 (Tufnell 1958:Pl. 35/36,219) (= Lalkin 2008:No. 399), but see, for example, the Bible+Orient Museum, Fribourg/Switzerland (Matouk 1971:211, No. 361).

20 These parallels were already mentioned by B. Brandl in Levy et al. (Levy, Adams, Najjar, Hauptmann, Anderson, Brandl, Robinson, and Higham 2004:874).

21 Alternatively, the standing human figure to the right may be interpreted as a beater.

22 See also the item from Tel Jemmeh (Herrmann 1994:No. 177), where the assumed collar is broken off and two fragmentary collars from Megiddo, Stratum V (Herrmann 1994:No. 182) and Tel Jemmeh (Herrmann 1994:No. 183). All three items were found in Iron Age II contexts. 
23 For example, Hornung and Staehelin (1976:126-127) with some examples or Shuval in Keel et al. (1990:Nos. $2-3,11-17,49-52)$.

24 Note that the lion is also present in these series serving as the mount for the god Baal or as the animal accompanying the healing god Reshef or the so-called lord of the crocodiles (cf. Münger 2005:Pl. 23.3, 1518).

25 Note that only items from legal excavations are accounted for; compare with Münger (2011): catalogue entries Acco [Tell el-Fukhar] ${ }^{\circ} 13-^{\circ} 14$; Achzib 1. ${ }^{\circ}$; Arad 1; Beth Šean 3.6; Beth Šemeš 1.2; Tell el-Far'ah (S) 5."39; Tel Gerisa ${ }^{\circ} 1-2$; Kinneret ${ }^{\circ} 2$; Lachiš 2.5;

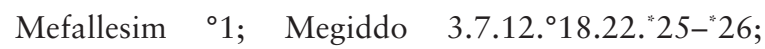
Tel Rekeš ${ }^{\circ} 1$; Tell es-Sa'idiyeh 1.7; see also Münger (2011:138) with notes xxv to xxvii for further, nonPalestinian parallels.

26 Compare with, for example, Tufnell (1984: Pl. 12,1555-1568).

27 During this period, they are usually paired with a single sign; compare with Lalkin (2008:Pl. 89,1621 ['anraformula in the center]; 1624-1630 [single $d d$-pillar in the center]; 1669 [winged scarab and cartouche filled with 'anra-signs in the center]); see also Brandl (2009: Fig. 12.29 = Keel 2010a:210-211, No. 250 [single $\underline{d} d$ pillar in the center; impression on bulla] for an item from Beth Shean, Stratum S-3a).

28 Furthermore, it is also frequent in the so-called Locusclypeus group of the Iron Age IIB (cf. Keel 2003).

29 Keel (2003) compares this base decoration with two earlier items from Tomb 934 at Tell el-Far'ah South (Keel 2010b:276-277, No. 576, and 322-323, No. 689); note, however, that the latter is quite differently executed; but see, for example, an item from Beth Shemesh, Tomb 11 (Keel 2010a:294-295, No. 176).

30 Examples are ${ }^{\circ}$ Tel Anafa (Keel 1997:642-643, No. 5); Tell el-Far'ah South, Tomb 934 (Keel 2010b:288289, No. 606); or Tel Harassim, Stratum IV (Lalkin 2008:No. 283).

31 Note that this epithet is already found on Middle Bronze Age II scarabs (cf., e.g., Keel 1995:Figs. 545 and 549 or Tufnell 1984:Pl. 58, 3284, 3286, 32883307).

32 For a comparable iconography, compare with, for exmaple, Beth Shemesh, Tomb 11 (Keel 2010a:266267, No. 114).

33 For a comparable situation in the Early Iron Age cemeteries at Tell el-Far'ah South, compare with Münger (2011:127-129).

\section{References}

Adams, R. B., and H. Genz.

1995 Excavations at Wadi Fidan 4: A Copper Village Complex in the Copper Ore District of Feinan, Southern Jordan. Palestine Exploration Quarterly 127:8-20.

Arav, R., and M. Bernett.

1997 An Egyptian Figurine of Pataikos at Bethsaida. Israel Exploration Journal 47:198-213.

Balensi, J., M. D. Herrera, and M. Artzy

1993 Art. Abu Hawam, Tell. In The New Encyclopedia of Archaeological Excavations in the Holy Land, edited by E. Stern, pp. 7-14. Israel Exploration Society \& Carta, Jerusalem.

Ben-Yosef, E., T. E. Levy, T. Higham, M. Najjar, and L. Tauxe

2010 The Beginning of Iron Age Copper Production in the Southern Levant: New Evidence from Khirbat al-Jariya, Faynan. Antiquity 84(325):724-746.

Ben-Tor, D.

1997 The Relations between Egypt and Palestine in the Middle Kingdom as Reflected by Contemporary Canaanite Scarabs. Israel Exploration Journal 47:162-189.

2007 Scarabs, Chronology, and Interconnections: Egypt and Palestine in the Second Intermediate Period. Orbis Biblicus et Orientalis. Series Archaeologica 27. Academic Press Fribourg, Fribourg, Switzerland.

Ben-Yosef, E.

2010 Technology and Social Process: Oscillations in Iron Age Copper Production and Power in Southern Jordan. Unpublished Ph.D. dissertation, University of California, San Diego.

Biran, A., and R. Gophna

1970 An Iron Age Burial Cave at Tel Halif. Israel Exploration Journal 20:152-169.

Brandl, B.

1993a Scarabs, a Scaraboid and a Scarab Impression from Area G (1968-1970). In Ashdod V: Excavations of Area G: The Fourth-Sixth Seasons of excavations 1968-1970, edited by M. Dothan and Y. Porath, pp. 129-143. 'Atiqot 23. Israel Antiquities Authority, Jerusalem.

1993b Scarabs and Other Glyptic Finds. In Shiloh: The Archaeology of a Biblical Site, edited by I. Finkelstein, pp. 203-222. Monograph Series 10. Tel-Aviv University, Institute of Archaeology, Tel Aviv, Israel. 
2003 The Cape Gelidonya Shipwreck Scarabs Reconsidered. In Synchronisation of Civilisations in the Eastern Mediterranean in the Second Millennium B.C. II, edited by M. Bietak, pp. 249261. Österreichische Akademie der Wissenschaften. Denkschriften der Gesamtakademie 29. Verlag der österreichischen Akademie der Wissenschaften, Wien, Germany.

2009 Scarabs, Seals, Sealings and Seal impressions. In Excavations at Tel Beth-Shean 1989-1996, Vol. 3: The 13th-11th Century BCE Strata in Areas N and $S$, edited by N. Panitz-Cohen and A. Mazar, pp. 636-684. Beth-Shean Valley Archaeological Project Publication 3. Israel Exploration Society, Jerusalem. Braunstein, S. L.

1998 The Dynamics of Power in an Age of Transition: An Analysis of the Mortuary Remains of Tell el-Far'ah (South) in the Late Bronze and Early Iron Ages. Unpublished Ph.D. dissertation, Graduate School of Arts and Sciences, Columbia University.

Brunton, G., and R. Engelbach

1927 Gurob. British School of Archaeology in Egypt Publications 41. British School of Archaeology in Egypt, London.

Dajani, R. W.

1970 A Late Bronze Age-Iron Age Tomb Excavated at Sahab, 1968. Annual of the Department of Antiquities of Jordan 15:29-34.

Dever, W. G. (editor)

1974 Gezer II: Report of the 1967-70 Seasons in Fields I and II. Annual of the Hebrew Union College Nelson Glueck School of Biblical Archaeology 2. Nelson Dodson, A. M. Glueck School of Biblical Archaeology, Jerusalem.

1993 A New King Shoshenq Confirmed? Göttinger Miszellen 137:53-58.

Eggler, J., and O. Keel

2006 Corpus der Siegel-Amulette aus Jordanien. Vom Neolithikum bis zur Perserzeit. Orbis Biblicus et Orientalis. Series Archaeologica 25. Academic Press Fribourg, Fribourg, Switzerland.

Fischer, C. S.

1929 The Excavation of Armageddon. The University of Chicago, Oriental Institute Communications 4. Chicago University Press, Chicago.

Gardiner, A. H.

1957 Egyptian Grammar: Being an Introduction to the Study of Hieroglyphs. Oxford University Press, Oxford, UK.
Giveon, R.

1969-1970 The Shosu of the Late XXth Dynasty. Journal of the American Research Center in Egypt 8:5153.

1971 Les Bédouins Shosou des Documents Egyptiens. E. J. Brill, Leiden, the Netherlands.

Giveon, S.

1988 Scarabs from Recent Excavations in Israel. Orbis Biblicus et Orientalis 83. Universitätsverlag, Fribourg, Switzerland.

Guy, P. L. O.

1938 Megiddo Tombs. The University of Chicago, Oriental Institute Publications 33. Chicago University Press, Chicago.

Hall, H. R.

1913 Catalogue of Egyptian Scarabs, etc., in the British Museum, Vol. 1: Royal Scarabs. The British Museum Press, London.

Hamilton, R. W.

1934 Excavations at Tell Abu Hawām. Quarterly of the Department of Antiquities in Palestine 4:1-69.

Herrmann, C.

1985 Formen für ägyptische Fayencen: Katalog der Sammlung des Biblischen Instituts der Universität Freiburg Schweiz und einer Privatsammlung. Orbis Biblicus et Orientalis 60. Universitätsverlag, Fribourg, Switzerland.

1994 Ägyptische Amulette aus Palästina/Israel. Mit einem Ausblick auf ihre Rezeption durch das Alte Testament. Orbis Biblicus et Orientalis 138. Universitätsverlag, Fribourg, Switzerland.

2003 Die ägyptischen Amulette der Sammlungen Bibel und Orient der Universität Freibourg Schweiz. Anthropomorphe Gestalten und Tiere. Orbis Biblicus et Orientalis. Series Archaeologica 22. Universitätsverlag, Fribourg, Switzerland.

2006 Ägyptische Amulette aus Palästina/Israel III. Orbis Biblicus et Orientalis. Series Archaeologica 22. Academic Press, Fribourg, Switzerland.

Hornung, E., and E. Staehelin (editors)

1976 Skarabäen und andere Siegelamulette aus Basler Sammlungen. Ägyptische Denkmäler in der Schweiz 1. Philipp von Zabern, Mainz, Germany.

Jaeger, B.

1982 Essai de classification et datation des scarabées Menkhéperrê. Orbis Biblicus et Orientalis. Series Archaeologica 4. Universitätsverlag, Fribourg, Switzerland. 
Jansen-Winkeln, K.

2007 Inschriften der Spätzeit, Vol. 2: Die 22.-24. Dynastie. Harrassowitz, Wiesbaden, Germany.

Keel, O.

1995 Corpus der Stempelsiegel-Amulette aus Palästinal Israel. Von den Anfängen bis zur Perserzeit. Einleitung. Orbis Biblicus et Orientalis. Series Archaeologica 10. Universitätsverlag, Fribourg, Switzerland.

1997 Corpus der Stempelsiegel-Amulette aus Palästinal Israel: von den Anfängen bis zur Perserzeit, Vol. 1: Von Tell Abu Fara $\breve{g}$ bis 'Atlit. Orbis Biblicus et Orientalis. Series Archaeologica 13. Universitätsverlag, Fribourg, Switzerland.

2003 Die Lotos-Kopfschild-Gruppe: Neo-Hyksos Skarabaeen der Eisenzeit IIB (ca. 900-700 v. u. Z.). pp. 127-157 in Saxa loquentur. Festschrift für Volkmar Fritz zum 65. Geburtstag, ed. C. den Hertog, U. Hübner and S. Münger. Alter Orient und Altes Testament 302. Ugarit Verlag, Münster, Germany.

2004 Scarabs, Stamp Seal-amulets and Impressions. In The Renewed Archaeological Excavations at Lachish (1973-1994), edited by D. Ussishkin, pp. 15371571. Tel Aviv University, Institute of Archaeology, Monograph Series 22. Emery and Claire Yass Publications in Archaeology, Tel-Aviv, Israel.

2010a Corpus der Stempelsiegel-Amulette aus Palästinal Israel: von den Anfängen bis zur Perserzeit, Vol. 2: Von Bahan bis Tel Eton. Orbis Biblicus et Orientalis. Series Archaeologica 29. Academic Press, Fribourg, Switzerland.

2010b Corpus der Stempelsiegel-Amulette aus Palästinal Israel: von den Anfängen bis zur Perserzeit, Vol. 3: Von Tell el-Far'a Nord bis Tell el-Fir. Orbis Biblicus et Orientalis. Series Archaeologica 31. Academic Press, Fribourg, Switzerland.

Keel, O., M. Shuval, and C. Uehlinger

1990 Studien zu den Stempelsiegeln aus Palästina/Israel III. Die frühe Eisenzeit. Ein Workshop. Orbis biblicus et orientalis 100. Universitätsverlag, Fribourg, Switzerland.

Keel, O., and C. Uehlinger

1998 Göttinnen, Götter und Gottessymbole. Neue Erkenntnisse zur Religionsgeschichte Kanaans und Israels aufgrund bislang unerschlossener ikonographischer Quellen, 4th ed. with supplement. Quaestiones disputatae 134. Herder, Freiburg im Breisgau, Germany.
Kitchen, K. A.

1986 The Third Intermediate Period in Egypt (1100-650 B.C.). 2nd ed. with supplement. Aris and Phillips, Warminster, Philadelphia.

2003 On the Reliability of the Old Testament. Eerdmans, Grand Rapids, Michigan.

Laemmel, S.

2003 A Case Study of the Late Bronze and Early Iron Age Cemeteries of Tell el-Far'ah South. Unpublished Ph.D. dissertation, Oxford University, Oxford, UK. Lalkin, N.

2008 Late Bronze Age Scarabs from Eretz Israel. Unpublished Ph.D. dissertation, Tel Aviv University, Tel Aviv, Israel.

Lamon, R. S., and G. M. Shipton

1939 Megiddo I. Seasons of 1925-34, Strata I-V. The University of Chicago, Oriental Institute Publications 42. Chicago University Press, Chicago.

Levy, T. E., R. B. Adams, and A. Muniz

2004 Archaeology and the Shasu Nomads-Recent Excavations in the Jabal Hamrat Fidan, Jordan. In Le-David Maskil: A Birthday Tribute for David Noel Freedman, edited by W. H. C. Propp and R. E. Friedman, pp. 63-89. Eisenbrauns, Winona Lake, Indiana.

Levy, T. E., R. B. Adams, M. Najjar, A. Hauptmann, J. A. Anderson, B. Brandl, M. A. Robinson, and T. Higham

2004 Reassessing the Chronology of Biblical Edom: New Excavations and ${ }^{14} \mathrm{C}$ Dates from Khirbat en-Nahas (Jordan). Antiquity 78:865-879.

Levy, T. E., R. B. Adams, and R. Shafiq

1999 The Jabal Hamrat Fidan Project: Excavations at the Wadi Fidan 40 Cemetery, Jordan (1997). Levant 31:293-308.

Levy, T. E., E. Ben-Yosef, and M. Najjar

2012 New Perspectives on Iron Age Copper Production and Society in the Faynan Region, Jordan. In Eastern Mediterranean Metallurgy and Metalwork in the 2 nd Millennium BC, edited by V. Kassianidou and G. Papasavvas, pp. 197-214. Oxbow Books, Oxford, UK.

Levy, T. E., T. Higham, C. Bronk Ramsey, N. G. Smith, E. Ben-Yosef, M. Robinson, S. Münger, K. Knabb, J. P. Schulze, M. Najjar, and L. Tauxe

2008 High-Precision Radiocarbon Dating and Historical Biblical Archaeology in Southern Jordan. Proceedings of the National Academy of Sciences 43:16450-16465. 
Levy, T. E., and M. Najjar

2006 Edom and Copper-The Emergence of Ancient Israel's Rival. Biblical Archaeology Review 32(4):24-35, 70.

Levy, T. E., M. Najjar, and T. Higham

2007 Iron Age Complex Societies, Radiocarbon Dates and Edom: Working with Data and Debates. Antiguo Oriente 5:13-34.

Levy, T. E., M. Najjar, A. Muniz, S. Malena, E. Monroe, M. Beherec, N. G. Smith, T. Higham, S. Münger, and K. Maes

2005 Iron Age Burial in the Lowlands of Edom: The 2004 Excavations at Wadi Fidan 40, Jordan. Annual of the Department of Antiquities of Jordan 49:443-487.

Levy, T. E., M. Najjar, J. van der Plicht, N. G. Smith, H. J. Bruins, and T. Higham

2005 Lowland Edom and the High and Low Chronologies: Edomite State Formation, the Bible and Recent Archaeological Research in Southern Jordan. In The Bible and Radiocarbon DatingArchaeology, Text and Science, edited by T. E. Levy and T. Higham, pp. 129-163. Equinox, London.

Levy, Y.

1993 Rishon Leziyyon Sand Dunes: Excavations and Surveys 13:57-59.

Loud, G.

1948 Megiddo II: Seasons of 1935-39. The University of Chicago, Oriental Institute Publications 62. Chicago University Press, Chicago.

Macalister, R. A. S.

1912 The Excavation of Gezer: 1902-1905 and 19071909. Palestine Exploration Fund Publications. Murray, London.

Matouk, F. S.

1971 Corpus du scarabée égyptien, Vol. 1: Les scarabées royaux. Academie Libanaise, Beirut, Lebanon.

1977 Corpus du scarabée égyptien, Vol. 2: Analyse thématique. Academie Libanaise, Beirut, Lebanon.

Mlinar, C.

2004 The Scarab Workshops of Tell el-Dab'a. In Scarabs of the Second Millennium BC from Egypt, Nubia, Crete and the Levant: Chronological and Historical Implications, edited by M. Bietak and E. Czerny, pp. 107-140. Österreichische Akademie der Wissenschaften. Denkschriften der Gesamtakademie 35. Verlag der österreichischen Akademie der Wissenschaften, Wien, Austria.
Münger, S.

2003 Egyptian Stamp-Seal Amulets and Their Implications for the Chronology of the Early Iron Age. Tel Aviv 30:66-82.

2005 Stamp-Seal Amulets and Early Iron Age Chronology-An Update. In The Bible and Radiocarbon Dating: Archaeology, Text and Science, edited by T. E. Levy and T. Higham, pp. 381-404. Equinox, London.

2007 Stamp Seals and Seal Impressions. In Excavations at Kadesh Barnea (Tell el-Qudeirat) 1976-1982, edited by R. Cohen and H. Bernick-Greenberg, pp. 237-242. IAA Reports 34. Israel Antiquities Authority 2007, Jerusalem.

2009 «Handle with Care»-Notes on Stamp-Seal Impressions on Jar Handles and a Bulla from Early Iron Age Tell el-'Orēme/Tell el-'Orēme/Tēl Kinrōt. Zeitschrift des Deutschen Palästina-Vereins 125:116-138.

2011 Studien zur Frühen Eisenzeit. Unpublished Ph.D. dissertation, University of Bern, Switzerland.

Newberry, P. E.

1907 Scarab-shaped Seals. Catalogue général des antiquités égyptiennes du musée du Caire 32: 36001-37521. Constable, London.

Petrie, W. M. F.

1889 Historical Scarabs: A Series of Drawings from the Principal Collections. Nutt, London.

1914 Amulets: Illustrated by the Egyptian Collection in University College, London. Constable, London.

1928 Gerar. British School of Archaeology in Egypt Publications 43. British School of Archaeology in Egypt, London.

1930 Beth-Pelet I. Tell Fara. British School of Archaeology in Egypt Publications 48. British School of Archaeology in Egypt, London.

Reisner, G. A., C. S. Fisher, and D. G. Lyon

1924 Harvard Excavations at Samaria 1908-1910. Harvard Semitic Series 1-2. Harvard University Press, Cambridge, Massachusetts.

Ritner, R. K.

2009 The Libyan Anarchy: Inscriptions from Egypt's Third Intermediate Period. Writings from the Ancient World 21. E. J. Brill, Leiden, the Netherlands.

Rothenberg, B.

1988 The Egyptian Mining Temple at Timna. Researches in the Arabah 1. Institute for Archaeo-Metallurgical Studies, London. 
Schipper, B. U.

1999 Israel und Ägypten in der Königszeit. Die kulturellen Kontakte von Salomo bis zum Fall Jerusalems. Orbis Biblicus et Orientalis 170. Universitätsverlag, Fribourg, Switzerland. Shortland, A.

2005 Shishak, King of Egypt: The Challenges of Egyptian Calendrical Chronology. In The Bible and Radiocarbon Dating: Archaeology, Text and Science, edited by T. E. Levy and T. Higham, pp. 43-56. Equinox, London.

Singer-Avitz, L.

2008 The Earliest Settlement at Kadesh Barnea. Tel Aviv 35:73-81.

Stern, E. (editor)

1993 The New Encyclopedia of Archaeological Excavations in the Holy Land. Israel Exploration Society \& Carta, Jerusalem.

Tufnell, O.

1984 Studies on Scarab Seals II: Scarab Seals and Their Contribution to History in the Early Second Millennium B.C. Modern Egyptology Series. Aris and Phillips, Warminster, Pennsylvania.
Tufnell, O. (editor)

1958 Lachish IV (Tell ed-Duweir): The Bronze Age. The Wellcome Archaeological Research Expedition to the Near East Publications 4. Oxford University Press, Oxford, UK.

Tufnell, O., C. H. Inge, and G. L. Harding

1940 Lachish II (Tell ed-Duweir): The Fosse Temple. The Wellcome-Marston Archaeological Research Expedition to the Near East Publications 2. Oxford University Press, Oxford, UK.

von Beckerath, J.

1997 Chronologie des pharaonischen Ägypten. Die Zeitbestimmung der ägyptischen Geschichte von der Vorzeit bis $332 v$. Chr. Münchner ägyptologische Studien 46. Philipp von Zabern, Mainz, Germany.

1999 Handbuch der ägyptischen Königsnamen. 2nd revised and enlarged edition. Münchner ägyptologische Studien 49. Philipp von Zabern, Mainz, Germany.

Ward, W. A.

1972 The Shasu Bedouin. Notes on a Recent Publication. Journal of the Economic and Social History of the Orient 15:35-60. 